\title{
Potential integration of Chinese and European emissions trading market: welfare distribution analysis
}

\author{
$\mathrm{Ru} \mathrm{Li}^{1} \cdot$ Sigit Perdana ${ }^{2}$ (D) Marc Vielle ${ }^{2}$
}

Received: 16 December 2020 / Accepted: 31 May 2021 / Published online: 25 June 2021

(C) The Author(s) 2021

\begin{abstract}
Central to the aims of the Paris Agreement, an integrated carbon market could potentially be a practical bottom-up option for effective and efficient mitigation. This paper quantifies the welfare effects of integration of Emission Trading Scheme (ETS) between the European Union (EU) and China. Using the European version of the computable general equilibrium model GEMINI-E3, our assessment reveals that integrating trading markets benefits both regions through the decrease welfare costs from abatements. China's welfare improves through net gain of selling the allowance, while the EU experiences lower deadweight loss. This effect is stronger to some notable countries in the EU, with high energy-intensive industries such as Poland and the Czech Republic. While a few others, such as Netherlands and Ireland, face higher welfare costs from negative trade gain. Limiting the trade quotas to $40 \%$ captures most of the EU welfare gain coming from $\mathrm{CO}_{2}$ trading. Further analysis at the sectoral level reveals that market integration significantly minimizes the loss of competitiveness of European energy-intensive industries and reduces international leakage. Our finding thus confirms the potential of the emissions trading market as an effective instrument to facilitate multilateral coordination in global mitigation.
\end{abstract}

Keywords European Union · China · Paris Agreement · Computable general equilibrium model $\cdot$ Emissions trading system $\cdot$ Linking

Sigit Perdana

sigit.perdana@epfl.ch

$\mathrm{Ru} \mathrm{Li}$

liru1001@163.com

Marc Vielle

marc.vielle@epfl.ch

1 Center for Energy and Environmental Policy Research, Beijing Institute of Technology, Beijing, 100081, China

2 LEURE Laboratory, École Polytechnique Fédérale de Lausanne (EPFL), CH-1015, Lausanne, Switzerland 


\section{Introduction}

The Emission Trading Scheme (ETS) is widely known as a cost-effective means for mitigation. Through this mechanism, countries can meet their emissions target in a fair and sustainable way based on their economic capacities. The European Union (EU) is among 15 trading schemes that are currently operating around the world. It is the first carbon trading market with the largest cap-and-trade system, and it is a key instrument in achieving EU climate policy targets. Following its effectiveness in achieving abatement targets and its role as the forefront of global mitigation, the EU ETS is now promoting the development of the carbon market by linking compatible ETS scheme (European Commission 2013). One of the potential trading markets is China.

The Chinese ETS started in 2013 with the implementation of the seven pilot projects consecutively. It involves the two major cities of Beijing and Shanghai; two industrial municipalities, Tianjin and Chongqing; two provinces, Guangdong and Hubei, and special economic area of Shenzhen (Ji et al. 2021). More than 3000 firms are involved (Zhu et al. 2020), with the accumulated trading volume accounted for $91.1 \mathrm{Mt} \mathrm{CO}_{2}$ in 2019. The trading volume was lower due to the global pandemic in the year 2020 yet still significant, reaching 75.3 $\mathrm{Mt} \mathrm{CO}_{2}$ with a total value of CNY 2.2 billion. Seeing its potential, China escalates a nationwide ETS system in 2020, which only covers the power sector in the first phase (Wang et al. 2018). Once completed, it will be the largest carbon emissions trading market in the world (Ying and Jinhengi 2017; Yang et al. 2016).

In general, linking ETS is practical bottom-up option for mitigating global emissions (Newell et al. 2014). Market linkage diversifies the abatement cost between participants, reduces costs of compliance and fosters the liquidity of the market (Goers et al. 2012; Jaffe and Stavins 2008). As economic efficiency improves, ETS linkage will further promote technology transfer and sustainable development and support the creation of a larger, free global restriction of carbon market. More specific, linking EU with China's ETS will be a significant step in achieving global emission targets. The establishment of such an integrated ETS will bound to attract other countries and regions to join in the development of a global carbon market (European Commission 2013).

As a major economic and political actor in the world economy, China's progress with ETS is critical. With increasing demand for more significant abatements at the global scale, coordinated action between China and the EU's ETS could be a prominent solution for more effective global mitigation. Both roles in leading climate action are substantial, considering the US inconsistency in dealing with global mitigation. ${ }^{1}$

Nonetheless, integrating the EU and China's trading market faces some obstacles. There are number of technical barriers such as a fundamental difference between allowance system (Zeng et al. 2016), emissions coverage and compliance procedures (Duan et al. 2018). The EU ETS uses the absolute cap scheme and China's allowance is based on emissions intensity. This difference between absolute and relative emissions limit creates differences in scarcity of allowances and in abatement incentives. Furthermore, it affects the stringency and consistency of emissions target for the sectoral involved. China's long-term target tends to be undefined and opaque as it depends on the GDP and quantity of emissions simultaneously. The emissions coverage could also create barriers to linkage (Ying and Jinhengi 2017). Inclusion of indirect $\mathrm{CO}_{2}$ emissions, likewise in China's pilot, may be opposed by

\footnotetext{
${ }^{1}$ After its controversial withdraw during Trump's era, the USA recently returns to Paris Agreement with Biden's new administration.
} 
EU for its transparency and accountability. In addition to this, China non-compliance costs are relatively low relative to EU with its stringent penalty regime. These aspects equally need to be standardized should the market be unified.

An integrated market also raises questions on the economic outcomes in both regions if those markets converge into a single system. A further question is on how this converged single system between EU and China should be designed. Furthermore, based upon the current defined climate target and on the stabilization of the global mitigation, will integration make either China or EU better off. These policy questions is what this paper aims to address. This paper complements the existing literature by re-assessing and evaluating the potential integration between China and the EU ETS.

It starts with a brief discussion on climate change policy, then leads to the design of this potential linkage market.The analysis will be based on emission trajectories and economic forecasts up to the year 2040 using an adaptation of a recursive dynamic general computable equilibrium model of GEMINI-E3. This ensures the dynamic efficiency and its welfare implications to be fully captured. Two main scenarios of separated versus integrated market will be investigated and followed up with a comparative analysis in a welfare cost decomposition. It includes the welfare gain from trade on commodities and emission quotas, and the excess burden from the emission reduction. Different to previous studies, this study focuses on the economic impacts for each $28 \mathrm{EU}$ member states (MS), and on the optimal trading limit as full participation with limited trading quotas will be more feasible and politically acceptable.

Our analysis finds that integration between the EU and China's ETS gives positive implications in both regions, yet is more robust for Europe. Welfare cost abatements fall in the majority of MS, especially in countries with high energy intensive industries. Despite a few states experiencing negative gains from trade, limiting the trade quota to a certain threshold will ensure the optimum welfare gained for each MS, thus minimizing the political reluctance of this potential policy.

The remainder of this paper is structured as follows. Section 2 elaborates the climate policy in the EU and China and reviews of the current development of the ETS markets. It is then followed by a potential design scheme of the integrated market as the basis of the analysis. Section 3 particularizes the GEMINI-E3 model that is used to perform the welfare evaluation and decomposition. The scenario results are presented in Section 4, while Section 5 concludes the findings.

\section{Review on climate policies, development and potential integration of ETS markets}

\subsection{The EU climate policies and trading market}

The EU climate actions are directed by implementing a sustainable climate and energy policy (Tol 2012), aiming to achieve net-zero greenhouse gas (GHG) emissions by 2050 . The current policy includes at least 40\% cuts in GHG emissions from 1990 levels, 32\% share for renewable energy and $32.5 \%$ improvement in energy efficiency. There is a sectoral division between ETS and non-ETS sectors. The ETS covers energy-intensive industries and has set a 43\% emission reduction target for 2030 from 2005 level. The non-ETS sectors, which also include the fossil energy consumption of households, endeavor to cut $30 \% \mathrm{GHG}$ emissions from 2005. 
Table 1 European GHG emissions targets

'Authors' estimates as described in the text

\begin{tabular}{lccc}
\hline & 2020 & 2030 & 2040 \\
\hline ETS target in \% of 2005 level & $-21 \%$ & $-43 \%$ & $-68 \%$ \\
Non-ETS target in \% of 2005 level & $-10 \%$ & $-30 \%$ & $-50 \%$ \\
Total in \% of 1990 level & $-20 \%$ & $-40 \%$ & $-60 \%$ \\
\hline
\end{tabular}

The ETS constitutes an exchange-tradable permits market for firms, characterized by a uniform $\mathrm{CO}_{2}$ price (Venmans 2012). The allocation of allowances is primarily based on free allowances with some auctioning. The Commission estimated that $57 \%$ of the total amount of allowances were auctioned during 2013-2020, while the remaining allowances are available for free allocation. ${ }^{2}$ It is predicted that auctioning will become the default method in future allocations (Hepburn et al. 2006). For the non-ETS market, $\mathrm{CO}_{2}$ abatement objectives are based on the so-called "Effort Sharing Decision", where emission targets for MS adjusted to their economic capacity. Two rounds of burden-sharing were already defined, for the years $2020^{3}$ and 2030 (European Commission 2016b). Table 1 reports these targets for 2020, 2030 and 2040 for the ETS and the non-ETS sectors. ${ }^{4}$

The effectiveness of ETS to reduce emissions in the EU is unquestionable. It has been instrumental for effective mitigation strategies (Muûls et al. 2016). In the first 2 years of implementation, approximately 100 to $200 \mathrm{MtCO}_{2}$ were abated across all ETS sectors. ${ }^{5}$ ETS significantly reduced Europe's emission intensity by $3.35 \%$ during the second phase, which is $43 \%$ than the 2005 level.

There has been no detrimental effect on the economic performance since the first phase of implementation of the EU ETS (Hu et al. 2015; Bel and Joseph 2015). The power and manufacturing industries pass on the additional cost to consumer with relatively insignificant increase in output price. There was a small negative effect on return of capital, but no effect on employment, productivity and investment. ${ }^{6}$

\subsection{Chinese climate target and emissions trading scheme}

As the largest $\mathrm{CO}_{2}$ emitter and the second largest economy in the world, China targets to lower $\mathrm{CO}_{2}$ emissions per unit of GDP by 40 to $45 \%$ from the 2005 level by 2020 . Beyond 2020, China strives to peak the $\mathrm{CO}_{2}$ emissions in year 2030 or sooner, and to reduce $\mathrm{CO}_{2}$ emissions per unit of GDP by 60 to $65 \%$ compared to the 2005 level. The annual emission intensity is targeted to fall to a minimum rate of 3.3\% during 2005-2020 and 3.1\% during 2020-2030. Following this trend, the emission intensity is assumed to fall to a minimum annual rate of $2.9 \%$ during $2030-2040$ and at least by 75 to $80 \%$ lower from the 2005 level (Table 2).

\footnotetext{
${ }^{2}$ https://ec.europa.eu/clima/policies/ets/auctioning_en

${ }^{3}$ Adopted in 2007.

${ }^{4}$ The target for 2040 of the non ETS sector is not officially defined, but it is expected to be at least a $60 \%$ reduction of GHG emissions from 1990 levels.

${ }^{5}$ It represents 2.4 to $4.7 \%$ of total emission reduction.

6 To name a few EU case study, Nava et al. (2018), Löschel et al. (2019), and Schäfer (2019) confirm the positive impacts at sectoral levels especially in the power and the aviation industries. ETS encourages investments in a more efficient capital stock that will allow companies to produce more products with fewer inputs.
} 
Table 2 China's emission intensity targets

Authors' estimates as described in the text

\begin{tabular}{llll}
\hline & 2020 & 2030 & $2040^{\dagger}$ \\
\hline $\begin{array}{l}\text { Emission inten- } \\
\text { sity targets in \% } \\
\text { of } 2005 \text { level }\end{array}$ & -40 to $-45 \%$ & -60 to $-65 \%$ & -75 to $-80 \%$ \\
\hline
\end{tabular}

China's ETS follows a "Cap-and-Trade" system where a company needs one unit of carbon credits for every ton of GHG emission. The government controls the total amount of carbon emissions and manages the emission quota that could be given for free or by auction and trade with others. China's national ETS was officially launched in 2017 in the "National Carbon Emissions Trading Market Construction Plan (Power Generation Industry)" report (Lin and Jia 2019; Tang et al. 2020). At present, the market only covers the power industry sectors for its significant $\mathrm{CO}_{2}$ emissions. ${ }^{7}$

In line with the EU, analytical studies on individual implementations of ETS in China generally confirm the effectiveness of emission trading with comparatively minor negative impact on the economy. ${ }^{8}$ ETS helps to effectively reduce China's emissions with no significant distortion (Wu et al. 2016; Meng et al. 2018; Cao et al. 2019). The implication among sectors are different, with the largest impact on the employment on China's coal industry (Huang et al. 2019).

\subsection{Addressing differences and potential markets integration}

Integrating both the EU and Chinese trading markets has been a particular interest to further analysis in current research (Heindl and Voigt 2012; Fragkos et al. 2018). Its potential emerges with two factors, the lower abatement cost and the electricity sector (Zeng 2017). A relatively lower abatement cost attracts the EU to consider China as a potential market to offset their permits, while the electricity generation industry has been the largest source of $\mathrm{CO}_{2}$ emission in both regions.

Some studies addressed the economic impacts of this integration despite the focal points only cover the macro perspective in both regions. Details on the national level, particularly for EU MS, are still limited. A relevant analysis on this potential integration is offered by Gavard et al. (2013) by measuring the impact of trading in carbon permits between the EU ETS and Chinese electricity sector. Using the EPPA CGE model, they found the EU carbon price would decrease by more than $76 \%$ under condition of unlimited sector trading. The general equilibrium effect dominated the revenue effect to the advantage of the EU, but not China. The latest study by Gavard et al. (2016) also confirms this finding on the opposite welfare impact between China and the EU. Adding the USA to the integrated market, again, advances the EU and enables the USA have welfare improvements. However, China is still worse off.

Another study by Alexeeva and Anger (2016) also confirms positive welfare implications for the EU, but not for its trading partner. Despite not specifically addressing China in the analysis, this paper measures the welfare impacts and trade competitiveness for the EU and non-EU as trading partners. The EU's economic efficiency losses are diminished by

\footnotetext{
${ }^{7}$ Annual $\mathrm{CO}_{2}$ emissions reach 26 thousand tons, or annual energy consumption reaches 10 thousand tce. Table 10 in the appendix shows the comparison of seven pilot ETS and EU ETS.

${ }^{8}$ Literature measured the impact and effectiveness of a single ETS implementation, mostly focused in a specific country.
} 
integration, improving the terms of trade. The non-EU partner faces the opposite trade effect with competitiveness losses.

Other notable studies focusing on the sectoral analysis, however, conclude different results. Using the Global Responses to Anthropogenic Change in the Environment (GRACE) model, Liu and Wei (2016) find that the integrated market can help China achieve its renewable energy target accompanied by $\mathrm{CO}_{2}$ emissions and abatement cost reductions. Thus, China is relatively better off by market linkage, while integration will do the opposite for the EU's renewables. The recent study of $\mathrm{Li}$ et al. (2019) also confirms that unlimited linking of EU and Chinese ETSs can benefit the development of clean energy in China, but hinder to meet the EU's renewable energy target.

Several points can be drawn from the above literature. First, it is vital to review the welfare assessment cost of this potential integration scheme. From the macroeconomic perspective, the EU consistently obtains welfare gains while its trading partners experience positive welfare loss as a result of the linkage. However, this result may differ when observed from EU individual MS as each may differ in their energy structure. Following in importance is the second point, which is the representable level of sectoral aggregation in the model and a highly recursive dynamic model to capture this impact.

Another critical point is the limited trading option when both partners are able to achieve the optimal abatement target and avoid welfare losses. Hübler et al. (2014) points out that limited linking is more feasible in the mid term when both partners can achieve 5\% more $\mathrm{CO}_{2}$ emission reduction without additional welfare losses. However, the benefit for China is relatively small given the transfer volume is one third of the EU's reduction effort.

The last, yet arguably the most fundamental, is the scheme of market integration/ linkage between these two markets. Those analyses on the current literature are based on a general assumption of a market follows other markets, ${ }^{9}$ without addressing other challenges involved with an integrated market. In addition to their differences in cap system, there are other critical factors such as the way emissions are measured and the stringency of allowance systems, which symmetrically affects decisions made between both regions. Therefore, how the linkage should be designed is clearly instrumental.

Integration between China and EU ETS promises positive economical and political impacts. Differences in these two markets, however, could impede this potential linkage. This is fundamental, as each system implicates different key elements in the nature of the carbon market. The first element is the duration of the cap system. It reflects the compliance period and influences both the market expectation and the incentives for investment in the long run. Similar to the EU, China also sets its cap duration annually yet without an official trajectory. Despite successful pilots, the Chinese national cap has not yet been confirmed. Implementing a full national system in China is challenging and, without massive reform, the EU will face higher information cost compared to the pre-linkage scenario (Zeng et al. 2016). This factor should have been considered when developing an integrated scheme for further simulations in this paper, yet for simplicity, it is assumed that information cost will be relatively small and negligible. ${ }^{10}$

A striking distinction can be noticed between the absolute versus the intensity-based cap which impinges on scarcity, the abatement incentives, and variability of the cap. For

\footnotetext{
${ }^{9}$ In this case, China follow EU.

${ }^{10}$ Information cost is associated with searching, obtaining and analyzing information from an integrated market that will be more complex compare to pre-linkage. Well-developed EU ETS is transparent with annual cap in line with official trajectory and the price signals. The absence of official trajectory in China market gives higher information cost for EU.
} 
analytical purposes, the analysis follows the assumption that the cap system will converge into the absolute emission limit in this integrated market. This assumption relies on two instrumental factors. First, there is no fixed emission limit under intensity-based cap, which reflects unreliable price predictability and credibility. A pre-defined cap could be adjusted, as in the case of the pilots, but it is unclear how and when this post adjustment should be made. Second, under economic uncertainty, no fixed abatement can not either ensure the scarcity of allowance or the desired environmental outcome. In contrast, the absolute cap system always ensures this environmental target is met. ${ }^{11}$

In addition to this, both EU and Chinese ETS differ in terms of the industries covered and quota mechanism (Ji et al. 2018). While the energy and heavy chemical industries take part of the EU market, China ETS covers some traditional high energy-consuming and highemission industries. And China mainly allocated quota free of charge, with only $3 \%$ of the quota is distributed by auction or fixed price sale. This is far lower than the EU market where more than $50 \%$ allowances were allocated through auction recently. This paper takes these aspects into consideration, yet for simplicity and robustness of the analysis, the new integrated market scheme keeps the assumption that China's national ETS will be only applied to the electricity sector such as in the pilot project and quotas will be distributed through full auction in both markets.

Another element of differences is the stringency factor and its consistency over time. The EU has set $1.74 \%$ annual reduction in power generation, while no defined target for China has been set. To deal with this, the integrated market analysis relates this stringency factor into the Advanced Technology and Renewable Energy Development (AT \& RED) projection, following the previous study of (Tang et al. 2018). In addition to the Business as Usual (BAU), ${ }^{12}$ AT \& RED represents China's commitment to peak its emissions before 2030 while incorporating policies to improve the energy efficiency, to promote advanced technologies and to increase the share of renewable electricity generation. Under AT \& RED, the $\mathrm{CO}_{2}$ emissions will peak at $4842 \mathrm{MtCO}_{2}$ in 2023 , then decrease to $4755 \mathrm{MtCO}_{2}$ and to $4203 \mathrm{MtCO}_{2}$ in 2030 and 2040, respectively. With higher commitment of renewable used in generation, AT \& RED predicts a more significant emission reduction, achieving levels under $3000 \mathrm{MtCO}_{2}$ in 2040 (see Fig. 1).

For further simulations, China's commitment is divided into two. The AT \& RED represents China's low commitment for electricity generation and assuming lower $\mathrm{CO}_{2}$ marginal abatement cost in electricity generation to factor its high commitment. If additional $\mathrm{CO}_{2}$ emissions reductions are required, the electricity would have to undergo further abatement. ${ }^{13}$

\footnotetext{
${ }^{11}$ Under unexpected economy growth, the price of allowance may fluctuate while with intensity-based, an additional allowance could only be released via post adjustment.

${ }^{12}$ China's strategy of its green power industry is currently regulated under the 13th Five-Year Plan, where the BAU represents the emissions under the existing policies with no change in the share of renewable electricity generation. The $\mathrm{CO}_{2}$ emission from power generation will increase $1.4 \%$ per year, from $4451 \mathrm{MtCO}_{2}$ in 2015 to $6274 \mathrm{MtCO}_{2}$ in 2040 .

${ }^{13}$ The analysis uses a correcting factor equal to 1.5 , assuming that if a percentage point additional abatement is required in the overall economy, then the electricity sector would have to decrease emissions by 1.5 percentage point. This correcting factor is computed from runs performed with GEMINI-E3, where a uniform carbon tax is imposed in China. Based on this scenario, the marginal $\mathrm{CO}_{2}$ abatements of the electricity generation sector are estimated and compared to the rest of the economy. This leads to the 1.5 coefficient. With this assumption, the electricity sector has to decrease emissions by $54.9 \%$ with respect to the baseline emissions for its high commitment. Following this, the non-ETS emissions has to decrease by $29.2 \%$ and the overall Chinese emissions by $42.8 \%$. Refer to Table 4.
} 


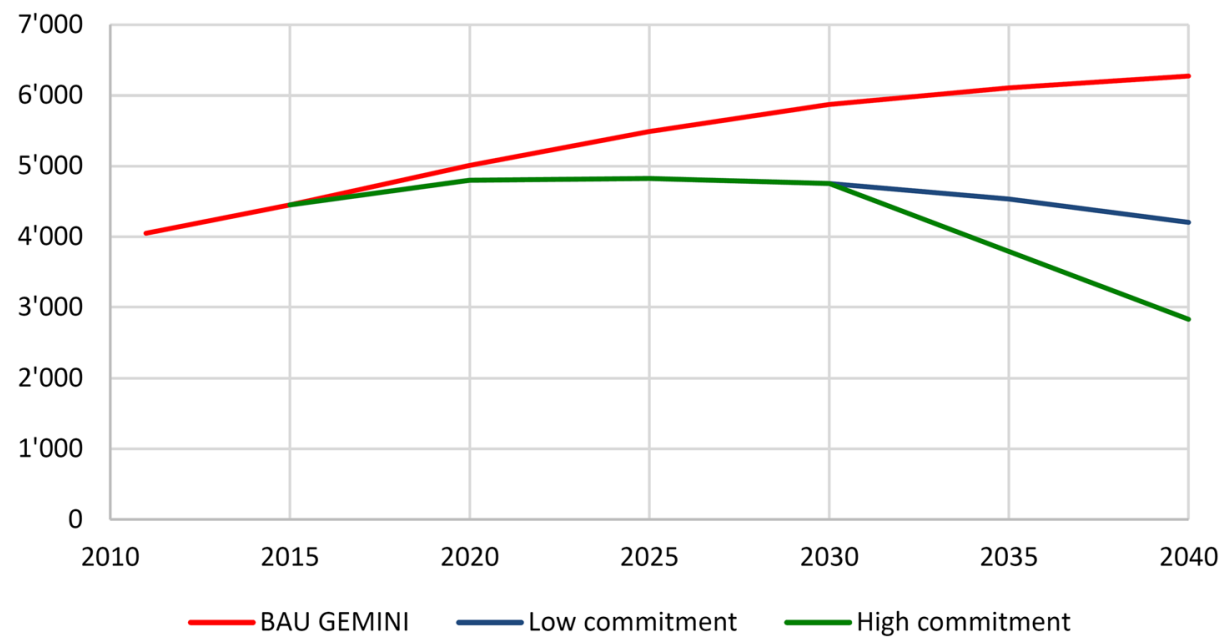

Fig. 1 Chinese emissions from electricity generation in $\mathrm{MtCO}_{2}$ - Reference and climate policy scenarios

Other significant differences to be addressed include the coverage of the ETS, compliance and monitoring scheme. The integrated market should only cover the direct $\mathrm{CO}_{2}$ emission since the inclusion of indirect $\mathrm{CO}_{2}$ under the current ETS market will face monitoring and accounting difficulties. Given the non-compliance costs are relatively low for China, this linkage market assumes a uniform stringent penalty regime to ensure participants will buy emission allowances instead of paying the fines. Borrowing allowances is considered acceptable and the monitoring scheme is transparent in both regions.

The last point of differences is on the definition of climate objectives which affects the time span on simulation periods. While the European Union has clearly defined its climate policy objectives for 2050, the Chinese goal was officially determined for the year 2030 through its Intended Nationally Determined Contributions (INDC). After year 2030, President Xi Jinping (Xi 2020) announced China's target to achieve carbon neutrality before year 2060, but short-term targets and followed up regulation remain undefined. This difference in climate policy objectives matters, affecting the assumption of Chinese target post 2030. For development in this paper, further simulations will be limited to year 2040, involving some assumptions on the Chinese target of 2031 to 2040. Analysis post 2040 will be challenging with increasing uncertainties on the design of the Chinese climate policy targets.

\section{The GEMINI-E3 model}

\subsection{Overview}

GEMINI-E3 is a multi-country, multi-sectoral and a recursive computable general equilibrium model (Bernard and Vielle 2008). ${ }^{14}$ The standard model is based on the assumption of total flexibility in all markets, i.e. both macroeconomic markets, such as capital and

\footnotetext{
${ }^{14}$ Comparative to other models of this class such as EPPA and OECD-Env-Linkage, or models built and implemented by other modeling teams and institution, GEMINI-E3 shares the same long experience in the design of this class of economic models.
} 
international trade markets (with associated prices being the real rate of interest and the real exchange rate, which are then endogenous), and microeconomic or sector markets (goods, factors of production, etc.).

\subsection{Key features of the model}

The current version is built on the GTAP 9 data base (Aguiar et al. 2016), with 2011 as the reference year. The spatial decomposition of this version of GEMINI-E3 describes each of the $28 \mathrm{EU}$ MSs as individual regions, plus China and the rest of the world. The number of sectors described by GEMINI-E3 is aggregated to 11 in order to have a tractable model and acceptable computation time. The classification is built in order to distinguish sectors participating in the ETS market from the others. The EU ETS sectors include petroleum products, electricity generation and energy-intensive industries. The latter industry comprises iron and steel, chemical, non-ferrous metals, non-metallic minerals products, and paper and the paper product. Three other energy goods are described by the model consist of coal, crude oil and natural gas. The remaining sectors are aggregated into agriculture, land transport, sea transport, air transport, and other goods and services.

For each sector, the model computes the demand of its production on the basis of household consumption, government consumption, exports, investment and intermediate uses. Total demand is then divided between domestic production and imports using the Armington assumption (Armington 1969), which assumes that domestic and imported goods are not perfectly homogenous. Production technologies are described by a nested Constant Elasticity of Substitution (CES) functions as shown in Appendix A.3.

Household's behavior consists of three interdependent decisions for labor supply, savings and consumption of the various goods and services. Both labor supply and saving rates are exogenous in the model. Demand on the different commodities has consumption and income price (more precisely "spent" income and income after savings), and is derived from a nested CES utility function as described in the Appendix A.4.

The government collects taxes and distributes the revenues to households and firms through transfers and subsidies. Wage is chosen as a numeraire in each region. The model is recursive dynamic, with backward looking (adaptive) expectations.

The analysis only considers $\mathrm{CO}_{2}$ emissions from energy combustion, while the non- $\mathrm{CO}_{2}$ emissions such as methane, nitrous oxide and fluorinated gases are not covered. The share of non- $\mathrm{CO}_{2} \mathrm{GHG}$ covered by the EU ETS emissions is quite limited. Only nitrous oxide from production of nitric, adipic, glyoxylic acids and glyoxal, and perfluorocarbons from aluminium production are included in the ETS market. They represent in 2018 less than $1 \%$ of European ETS emissions. The Chinese ETS does not included any non $\mathrm{CO}_{2}$ GHG emissions.

\subsection{Assessing welfare cost}

Like other computable general equilibrium models, GEMINI-E3 assesses the welfare cost of policies through compensating variation of income (CVI). This measure is preferable to change in GDP or change in households' final consumption since both are measured at constant prices that follows the methods of national accounting. Both fail to capture the change in the structure of prices, which is a main effect of climate change policies. The CVI is computed from the expenditure function $(e)$ using the standard formula:

$$
C V I=e\left(P_{0}, U_{0}\right)-e\left(P_{1}, U_{0}\right)
$$


where $U_{0}$ and $P_{0}$ are the utility level and the price system in the reference scenario, and $P_{1}$ the prices in the climate policy scenario.

In addition, it is essential to split the welfare cost between its two components, the domestic component or deadweight loss of taxation (DWL) and the imported component or gains from terms of trade (GTT). The GTT represents spill-over effects due to changes in international prices which are mainly due to the drop in fossil energy prices resulting from a decrease in world energy demand.

Decomposition of the welfare cost into components is certainly a complex issue. ${ }^{15}$ This paper aims to approximate decomposition between domestic and imported costs, in order to obtain a general idea of their relative importance (Bernard and Vielle 2003). This approach is justified by the fact that the change in price, particularly the price of foreign trade, is fairly small. In practice, compensative variation income is first calculated from the results of the model, and the specification and coefficients of the demand function. The GTT are then calculated based on the results of the involved scenario using the following equation:

$$
G T T=\sum_{i}\left(P \exp _{1, i}-P \exp _{0, i}\right) \cdot \text { Export }_{0, i}-\sum_{i}\left(\text { Pimp }_{1, i}-\text { Pimp }_{0, i}\right) \cdot \text { Import }_{0, i}
$$

where $P \exp _{1, i}$ and $P i m p_{1, i}$ represent the exports and imports prices (for product $i$ ) in the climate policy scenario, and Export $t_{0, i}$ and Import $_{0, i}$ represent the levels of exports and imports, respectively, in the reference scenario. Finally, the DWL is the difference between the compensative variation income and the GTT:

$$
D W L=C V I-G T T
$$

\section{Numerical analysis}

\subsection{Reference scenario}

The GEMINI-E3 reference scenario is built on the period 2011-2040 with yearly time steps with all prices given in $€_{2017 .}{ }^{16}$ Based on historical population and international energy prices of 2011 to 2015, the technical progresses associated with labor and energy consumption are estimated to reproduce historical GDP, energy consumption, and related $\mathrm{CO}_{2}$ emissions.

\subsubsection{The European Union}

The reference scenario implicitly considers all previous policies implemented since 2015, emphasizing those related to energy and climate fields. Assumptions about population, GDP and international energy prices post 2016 are based on the EU reference scenario 2016 (European Commission 2016a). It is projected that European GDP will grow by $1.5 \%$ annually between 2015 and 2040 while GDP growth rates for MS follow the projection of DG ECFIN (European Commission 2015b). For energy consumption and $\mathrm{CO}_{2}$ emissions after 2015, the reference scenario differs from the one computed in the EU scenario of 2016

\footnotetext{
${ }^{15}$ Refer to study by Böhringer and Rutherford (2002) in the case of climate change policy and Harrison et al. (2000) in a more general framework.

${ }^{16}$ The model is calibrated on the GTAP 9 data base, and therefore the economic variables are measured in US $\$_{2011}$. We compute figures in $€_{2017}$ by using the exchange rate between $€$ and US\$ for the year 2011 , and the European GDP deflator between 2011 and 2017 provided by Eurostat.
} 
since the analysis of this paper does not integrate additional climate abatements in the EUETS and new climate and energy policies. As shown in Fig. 2, the EU carbon emissions are stable along the forecast and reached $3.4 \mathrm{GtCO}_{2}$ in 2040.

\subsubsection{China}

China's GDP growth assumptions follows the World Energy Outlook (International Energy Agency 2019) where the annual GDP growth will decrease slightly to $3.7 \%$ at the end of the simulation (Table 3). In 2040, China's emissions will reach $11.9 \mathrm{GtCO}_{2}$ which represents one quarter of the $45.5 \mathrm{GtCO}_{2}$ world's emissions. Chinese emissions from electricity generation and heat production follow the same path that computed in Tang et al. (2018) for the BAU scenario. These emissions are expected to increase by $1.4 \%$ yearly from 2015 to 2040. In the same period, total Chinese $\mathrm{CO}_{2}$ emissions increase by $30 \%$, representing a $1 \%$ annual growth rate. Figure 3 illustrates these projected emissions. For the Rest of the World (ROW), abatement runs as BAU with no additional constraint. The GDP increases by $3.7 \%$ per year from 2015 to 2040 and the $\mathrm{CO}_{2}$ emissions reach $30 \mathrm{GtCO}_{2}$ in 2040.

\subsection{Non-integrated market scenario}

These scenarios assume that the EU and China implement their climate policies without integrating their ETS markets, and no emissions constraint in the Rest of the World (ROW). The EU ETS sectors participate in a $\mathrm{CO}_{2}$ tradable market with full auctioned emission allowances. The use of the auctioning revenues mainly follows the revised ETS directive of phase 4 (2021-2030). Within this directive 90\% of the allowances auctioned will be distributed to the EU MS on the basis of their share of verified emissions. The remaining $10 \%$ are allocated to the less wealthy EU MS for the purpose of solidarity, growth and interconnections. For simplicity and transparency, it is assumed that $100 \%$ of the allowances

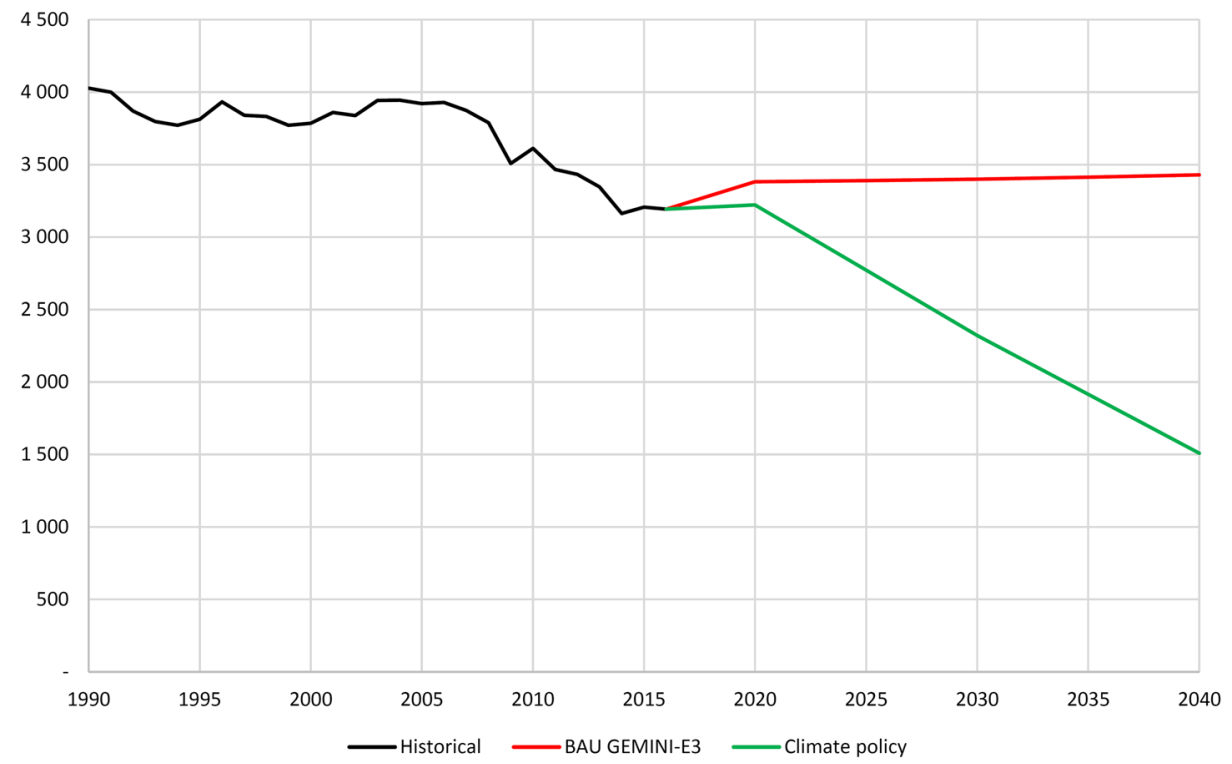

Fig. 2 European Union emissions in $\mathrm{Mt} \mathrm{CO}_{2}$ - Reference and climate policy scenarios 
Table 3 Key indicators on the reference scenario

\begin{tabular}{|c|c|c|c|}
\hline & $2015-2020$ & 2020-2030 & $2030-2040$ \\
\hline \multicolumn{4}{|c|}{ GDP growth per year in $\%$} \\
\hline EU28 & $1.5 \%$ & $1.4 \%$ & $1.5 \%$ \\
\hline China & $6.1 \%$ & $4.8 \%$ & $3.7 \%$ \\
\hline \multirow[t]{2}{*}{ World } & $3.1 \%$ & $3.6 \%$ & $3.4 \%$ \\
\hline & 2020 & 2030 & 2040 \\
\hline \multicolumn{4}{|c|}{ Total $\mathrm{CO}_{2}$ emissions in $\mathrm{MtCO}_{2}$} \\
\hline EU28 & 3,382 & 3,399 & 3,429 \\
\hline China & 9,790 & 11,078 & 11,871 \\
\hline World & 33,182 & 39,359 & 45,562 \\
\hline \multicolumn{4}{|c|}{ ETS $\mathrm{CO}_{2}$ emissions in $\mathrm{MtCO}_{2}$} \\
\hline EU28 & 1,629 & 1,648 & 1,670 \\
\hline China & 5,010 & 5,872 & 6,274 \\
\hline
\end{tabular}

auctioned are redistributed to EU MS on the basis of their verified emissions. The European Commission (EC) collects and redistributes to the allowances to MS based on their emissions shares.

Following this assumption, the non-ETS sectors implement a domestic $\mathrm{CO}_{2}$ tax, based on the Effort Sharing Regulation (ESR) targets presented in the Appendix A.2. ${ }^{17}$ Firms included in the ESR emissions and households pay a domestic $\mathrm{CO}_{2}$ tax on their fossil energy consumption. The $\mathrm{CO}_{2}$ tax revenue is redistributed to households through a lump-sum transfer.

On the other hand, China's ETS market only includes the electricity generation while others are subject to a Chinese $\mathrm{CO}_{2}$ tax. The revenue gained from ETS allowances and $\mathrm{CO}_{2}$ tax follow the same rules used for European countries. There are two additional assumptions for China's commitments on total $\mathrm{CO}_{2}$ emissions: a low and a high commitment as described in Section 2.2 and represented in Fig. 3.

Table 4 shows the main results of non-integrated market scenario of the EU and China. Regardless of China's emissions commitment, the non-integrated EU market results in a $52 \%$ effective abatement in 2040. The carbon price in the EU ETS is estimated to reach 45 $€$ in 2030 and $277 €$ in 2040 . Non-ETS carbon prices are much higher with large differences across MS. The averaged ESR price ${ }^{18}$ is estimated to equal to $209 €$ in 2030 and $834 €$ in 2040. The European welfare cost reaches around $2 \%$ of households consumption in 2040.

For China, the design of the low and high commitment scenarios results in the same $\mathrm{CO}_{2}$ prices for 2030. Indeed, the stringency of Chinese ETS targets differs only after 2031 (see Fig. 1), and the reductions in non-ETS emissions induced by the increasing electricity price are sufficient to reach the low and high commitments for total $\mathrm{CO}_{2}$ emissions in 2030 . Therefore, the non-ETS $\mathrm{CO}_{2}$ price is equal to zero in both scenarios.

But in 2040, the two scenarios lead to different figures. Chinese low commitment results in a $28 \%$ abatement in effective emissions in 2040 , and a $43 \%$ reduction when highly

\footnotetext{
${ }^{17}$ The aim of this paper is not to analyse the EU burden sharing, such analysis has been already performed and published in Vielle (2020).

${ }^{18}$ The average $\mathrm{CO}_{2}$ price is weighted with the emissions of the scenario.
} 


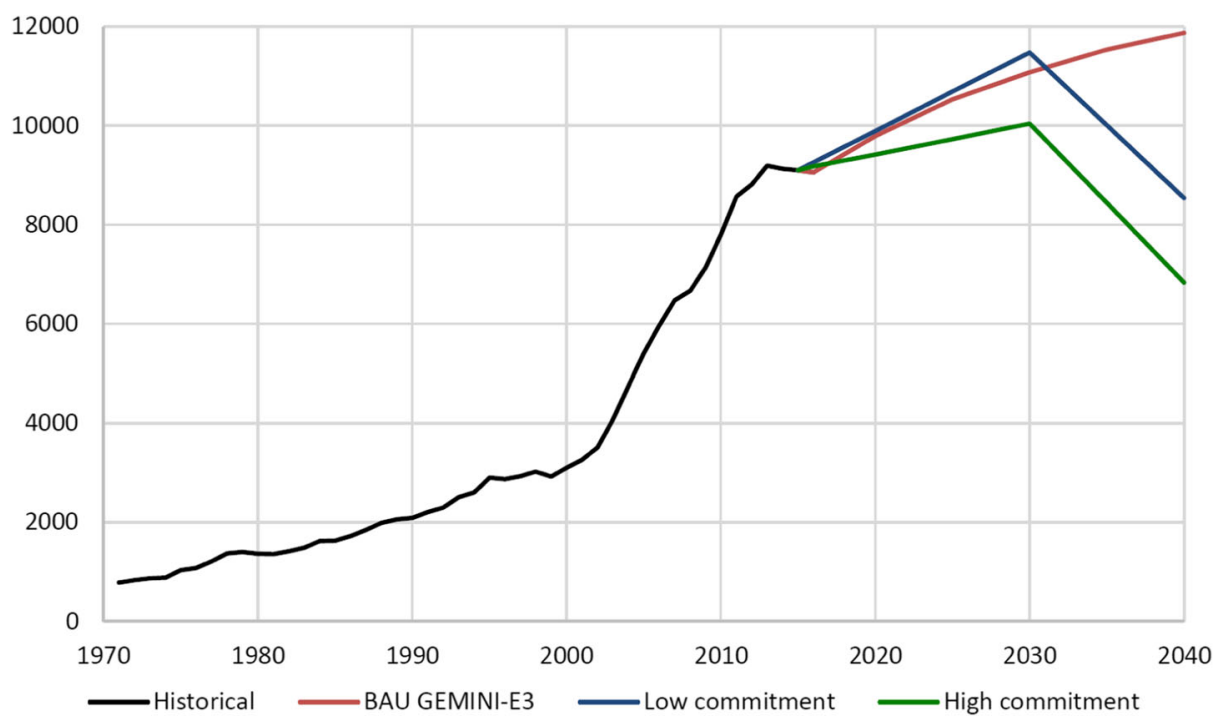

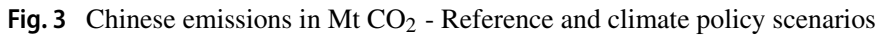

Table 4 Scenario results non-integrated markets

\begin{tabular}{|c|c|c|c|c|}
\hline & \multicolumn{2}{|c|}{ Low commitment } & \multicolumn{2}{|c|}{ High commitment } \\
\hline & 2030 & 2040 & 2030 & 2040 \\
\hline \multicolumn{5}{|c|}{ Total emissions change* } \\
\hline EU28 & $-25.8 \%$ & $-51.9 \%$ & $-25.8 \%$ & $-51.9 \%$ \\
\hline China & $-9.2 \%$ & $-28.3 \%$ & $-9.4 \%$ & $-42.8 \%$ \\
\hline \multicolumn{5}{|c|}{ ETS emissions change* } \\
\hline EU28 & $-35.4 \%$ & $-64.6 \%$ & $-35.4 \%$ & $-64.6 \%$ \\
\hline China & $-19.0 \%$ & $-33.0 \%$ & $-19.0 \%$ & $-54.9 \%$ \\
\hline \multicolumn{5}{|c|}{ Non-ETS emissions change* } \\
\hline EU28 & $-16.8 \%$ & $-39.9 \%$ & $-16.8 \%$ & $-39.9 \%$ \\
\hline China & $1.8 \%$ & $-23.0 \%$ & $1.4 \%$ & $-29.2 \%$ \\
\hline \multicolumn{5}{|c|}{ ETS price in $€$} \\
\hline EU28 & 45 & 277 & 45 & 277 \\
\hline China & 5 & 11 & 5 & 28 \\
\hline \multicolumn{5}{|c|}{ Non-ETS price $€$} \\
\hline EU28 & 209 & 834 & 209 & 834 \\
\hline China & 0 & 11 & 0 & 15 \\
\hline \multicolumn{5}{|c|}{ Welfare change $^{\dagger}$} \\
\hline EU28 & $-0.15 \%$ & $-2.09 \%$ & $-0.15 \%$ & $-2.10 \%$ \\
\hline China & $-0.46 \%$ & $-1.47 \%$ & $-0.45 \%$ & $-2.13 \%$ \\
\hline
\end{tabular}

* Percentage change with respect to baseline emissions

${ }^{\dagger}$ In percentage of household consumption 
committed. The carbon price in the ETS market is approximated to reach $11 €$ in 2040 , indicating that significant carbon abatement opportunities in Chinese electricity generation is mainly contributed by coal power plants. This increases quite significantly and reaches $28 €$ in 2040 if the commitment is high. China's carbon tax, in contrast, shows insignificant changes when the commitment is high. This further indicates the stringency of this scenario for ETS emissions as shown in Fig. 4. China's $\mathrm{CO}_{2}$ prices are relatively low, compared to the EU with the welfare costs reach 1.47 and $2.44 \%$ of household consumption for the low and high commitment scenarios, respectively.

\subsection{Integrated market scenario}

Integrating ETS markets requires defining how the quotas sold by China will be paid by the EU MS. This scenario follows the logic of the ETS auctioning allocation rule used by European Comission, assuming that quotas bought by EU are paid by MS on the basis of their ETS emissions. If a country emits $10 \%$ of EU ETS emissions, it has to pay $10 \%$ of quotas sold by China. This is the allowance allocation for each European country from the nonintegrated scenario described in the previous section. These allowances reflect an efficient allocation within the EU that equalizes the marginal abatement cost within firms and countries to the European ETS price. In this scenario, the integrated ETS market gives positive impacts for both regions, despite stronger trading gains by the EU. Table 5 lists the results.

Initially, when China's commitment is low, the common ETS price reaches just $17 €$ in 2040. European welfare improves as the cost decreases from 2.09 to $1.56 \%$. Chinese welfare cost is reduced to $1.35 \%$, compared to $1.47 \%$ with no integration (Table 6). When the ETS markets are merged, the EU has to provide less abatement, from 64.6 to $24.8 \%$ in 2040 . It reduces the DWL from $4.72 \%$ of household consumption to $3.85 \%$. The EU MS have to buy Chinese quotas, which represents $0.11 \%$ of their household consumption. The gain of trading is estimated to be $0.53 \%$ of household consumption (2.09 to $1.56 \%$ ). China is of course faced with an opposite situation. A greater abatement is required in electricity generation, but selling of quotas represents an additional $0.24 \%$ of the household consumption. The net gain of trading is equal to $0.12 \%$ of household consumption in 2040 (i.e. 1.47 to $1.35 \%$ ).

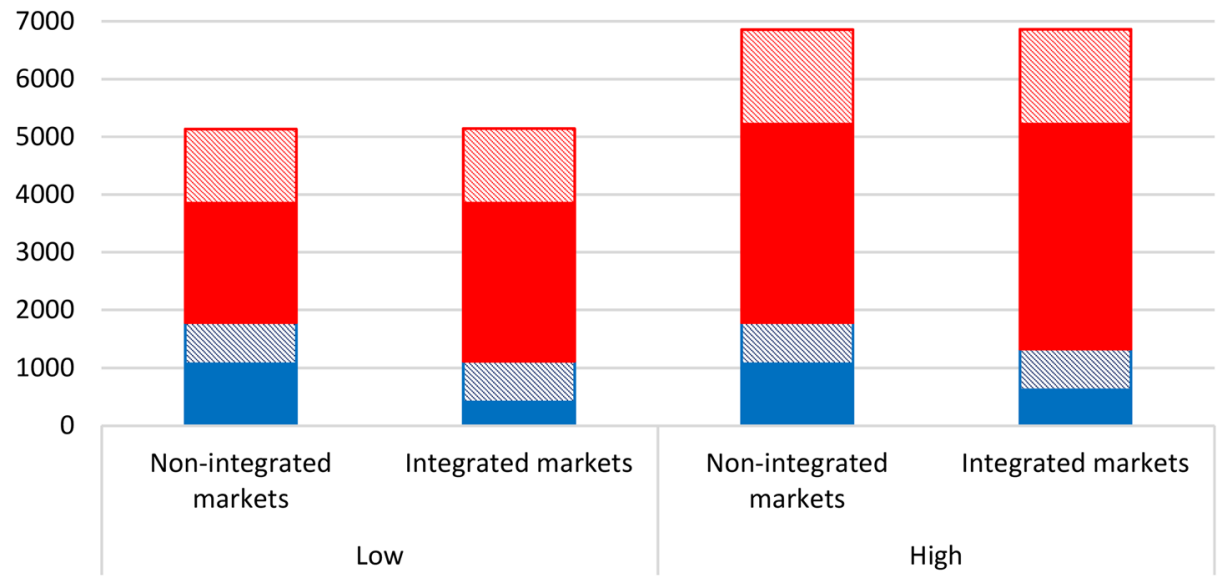

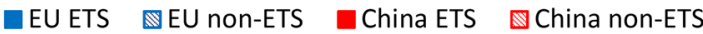

Fig. 4 Abatement in $\mathrm{Mt} \mathrm{CO}_{2}$ - Year 2040 
Table 5 Scenario results integrated markets

\begin{tabular}{|c|c|c|c|c|}
\hline & \multicolumn{2}{|c|}{ Low commitment } & \multicolumn{2}{|c|}{ High commitment } \\
\hline & 2030 & 2040 & 2030 & 2040 \\
\hline \multicolumn{5}{|c|}{ Total emissions change* } \\
\hline EU28 & $-14.3 \%$ & $-32.5 \%$ & $-14.3 \%$ & $-38.7 \%$ \\
\hline China & $-12.5 \%$ & $-33.9 \%$ & $-13.0 \%$ & $-46.6 \%$ \\
\hline \multicolumn{5}{|c|}{ ETS emissions change* } \\
\hline EU28 & $-11.6 \%$ & $-24.8 \%$ & $-11.6 \%$ & $-37.5 \%$ \\
\hline China & $-25.7 \%$ & $-43.6 \%$ & $-25.7 \%$ & $-62.1 \%$ \\
\hline \multicolumn{5}{|c|}{ Non-ETS emissions change* } \\
\hline EU28 & $-16.8 \%$ & $-39.8 \%$ & $-16.8 \%$ & $-39.8 \%$ \\
\hline China & $2.3 \%$ & $-23.1 \%$ & $1.3 \%$ & $-29.3 \%$ \\
\hline \multicolumn{5}{|c|}{ ETS price in $€$} \\
\hline EU28 & 8 & 17 & 8 & 40 \\
\hline China & 8 & 17 & 8 & 40 \\
\hline \multicolumn{5}{|c|}{ Non-ETS price $€$} \\
\hline EU28 & 216 & 908 & 216 & 897 \\
\hline China & 0 & 6 & 0 & 8 \\
\hline \multicolumn{5}{|c|}{ Welfare change $^{\dagger}$} \\
\hline EU28 & $-0.13 \%$ & $-1.56 \%$ & $-0.13 \%$ & $-1.74 \%$ \\
\hline China & $-0.41 \%$ & $-1.35 \%$ & $-0.41 \%$ & $-1.93 \%$ \\
\hline
\end{tabular}

${ }^{*}$ Percentage change with respect to baseline emissions

${ }^{\dagger}$ In percentage of household consumption

When China's abatement commitment is high, our simulation reveals the same trends yet at a different magnitude. The net gain equals 0.36 and $0.2 \%$ of household consumption for the EU and China, respectively.

Table 6 Welfare decomposition in $\%$ of household consumption Year 2040

\begin{tabular}{llllll}
\hline & \multicolumn{2}{l}{ Low } & & & High \\
\cline { 2 - 3 } \cline { 5 - 5 } & Without & With & & Without & With \\
\hline EU28 & & & & \\
Welfare & $-2.09 \%$ & $-1.56 \%$ & $-2.10 \%$ & $-1.74 \%$ \\
GTT & $2.63 \%$ & $2.39 \%$ & $2.62 \%$ & $2.37 \%$ \\
Trade of quotas & - & $-0.11 \%$ & - & $-0.17 \%$ \\
DWL & $-4.72 \%$ & $-3.85 \%$ & $-4.72 \%$ & $-3.94 \%$ \\
China & & & & $-1.93 \%$ \\
Welfare & $-1.47 \%$ & $-1.35 \%$ & $-2.13 \%$ & $-0.67 \%$ \\
GTT & $-0.90 \%$ & $-0.82 \%$ & $-0.81 \%$ & $-0.68 \%$ \\
Trade of quotas & - & $0.24 \%$ & - & $-1.64 \%$ \\
DWL & $-0.57 \%$ & $-0.77 \%$ & $-1.32 \%$ & \\
\hline
\end{tabular}




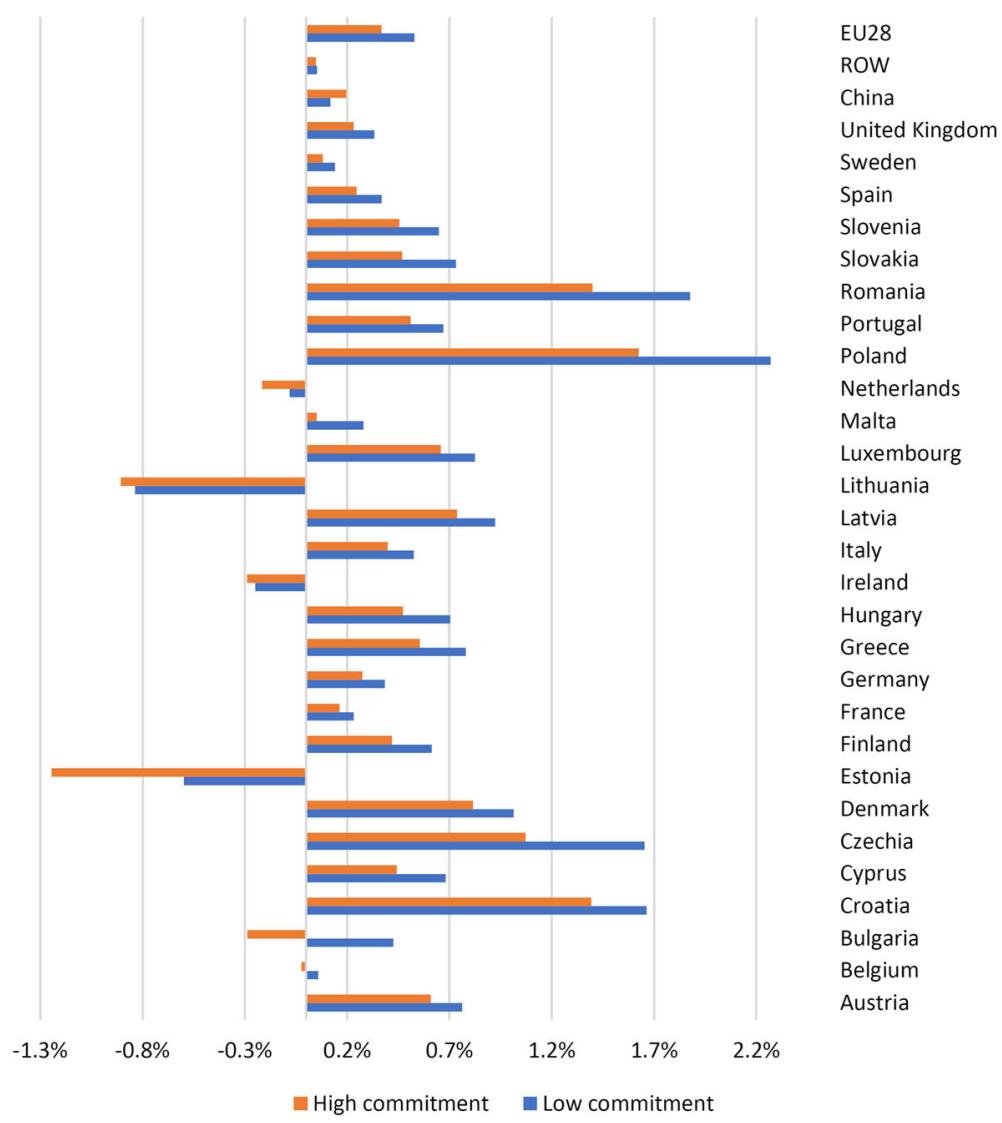

Fig. 5 Welfare change in \% of household consumption-year 2040

\subsection{Impacts per member states, energy intensive industries and leakage}

Figure 5 shows the welfare changes for the year 2040 in each MS when ETS markets are integrated. Poland, Romania, Croatia and the Czech Republic (Czechia) gain positive impacts as their welfare improves by more than $1.5 \%$ in terms of household consumptions. For these new member states, ETS sectors constitute a larger part of the economy (Brink et al. 2016); thus, the reduction of the ETS price is highly beneficial. Some European countries are worse off; however, their losses in terms of trade overcompensate the decrease in the DWL. ${ }^{19}$ Lithuania, Ireland, Estonia and the Netherlands are predicted to have up to $1 \%$ welfare loss (higher welfare costs) of their household consumptions.

Table 7 lists the exchange of quotas in $\mathrm{MtCO}_{2}$. In the low commitment scenario, it is estimated $664 \mathrm{MtCO}_{2}$ sold by China to the EU in 2040. A higher commitment, places China under pressure to reduce this quota to only $452 \mathrm{MtCO}_{2}$ sold, representing $76.5 \%$ of the $\mathrm{EU}$ ETS target in 2040. The EU's main buyers are the larger countries of Germany, UK, Italy and Spain, and the countries that consume a lot of fossil energy in ETS sectors such as

\footnotetext{
${ }^{19}$ It confirms the previous finding of Babiker et al. (2004).
} 
Table 7 ETS abatement, allowances and trading of quotas with China per Member State

\begin{tabular}{|c|c|c|c|c|c|c|}
\hline & \multicolumn{3}{|c|}{ Low commitment scenario } & \multicolumn{3}{|c|}{ High commitment scenario } \\
\hline & $\begin{array}{l}\text { Abatement } \\
\text { without } \\
\text { trading }\end{array}$ & $\begin{array}{l}\text { Abatement } \\
\text { with } \\
\text { trading }\end{array}$ & $\begin{array}{l}\text { Trade } \\
\text { in } \mathrm{MtCO}_{2}\end{array}$ & $\begin{array}{l}\text { Abatement } \\
\text { without } \\
\text { trading }\end{array}$ & $\begin{array}{l}\text { Abatement } \\
\text { with } \\
\text { trading }\end{array}$ & $\begin{array}{l}\text { Trade } \\
\text { in } \mathrm{MtCO}_{2}\end{array}$ \\
\hline Austria & $-53 \%$ & $-19 \%$ & -9 & $-53 \%$ & $-27 \%$ & -7 \\
\hline Belgium & $-54 \%$ & $-18 \%$ & -15 & $-54 \%$ & $-26 \%$ & -11 \\
\hline Cyprus & $-39 \%$ & $-4 \%$ & -2 & $-39 \%$ & $-10 \%$ & -1 \\
\hline Czechia & $-74 \%$ & $-29 \%$ & -26 & $-74 \%$ & $-46 \%$ & -17 \\
\hline Denmark & $-72 \%$ & $-33 \%$ & -8 & $-72 \%$ & $-48 \%$ & -5 \\
\hline Estonia & $-43 \%$ & $-5 \%$ & -5 & $-43 \%$ & $-11 \%$ & -4 \\
\hline Finland & $-61 \%$ & $-23 \%$ & -13 & $-61 \%$ & $-34 \%$ & -9 \\
\hline France & $-50 \%$ & $-19 \%$ & -40 & $-50 \%$ & $-27 \%$ & -30 \\
\hline Germany & $-70 \%$ & $-25 \%$ & -148 & $-70 \%$ & $-39 \%$ & -99 \\
\hline Greece & $-59 \%$ & $-16 \%$ & -15 & $-59 \%$ & $-29 \%$ & -10 \\
\hline Hungary & $-55 \%$ & $-20 \%$ & -8 & $-55 \%$ & $-30 \%$ & -6 \\
\hline Ireland & $-63 \%$ & $-26 \%$ & -6 & $-63 \%$ & $-37 \%$ & -4 \\
\hline Italy & $-56 \%$ & $-21 \%$ & -66 & $-56 \%$ & $-31 \%$ & -48 \\
\hline Latvia & $-48 \%$ & $-10 \%$ & -1 & $-48 \%$ & $-18 \%$ & -1 \\
\hline Lithuania & $-41 \%$ & $-14 \%$ & -2 & $-41 \%$ & $-20 \%$ & -2 \\
\hline Luxembourg & $-53 \%$ & $-12 \%$ & -1 & $-53 \%$ & $-21 \%$ & -1 \\
\hline Malta & $-41 \%$ & $-6 \%$ & -1 & $-41 \%$ & $-12 \%$ & -1 \\
\hline Netherlands & $-54 \%$ & $-23 \%$ & -27 & $-54 \%$ & $-32 \%$ & -19 \\
\hline Poland & $-76 \%$ & $-30 \%$ & -77 & $-76 \%$ & $-48 \%$ & -47 \\
\hline Portugal & $-62 \%$ & $-25 \%$ & -9 & $-62 \%$ & $-37 \%$ & -6 \\
\hline Slovakia & $-55 \%$ & $-19 \%$ & -7 & $-55 \%$ & $-30 \%$ & -5 \\
\hline Slovenia & $-67 \%$ & $-19 \%$ & -3 & $-67 \%$ & $-33 \%$ & -2 \\
\hline Spain & $-59 \%$ & $-24 \%$ & -51 & $-59 \%$ & $-34 \%$ & -36 \\
\hline Sweden & $-46 \%$ & $-19 \%$ & -7 & $-46 \%$ & $-27 \%$ & -5 \\
\hline United Kingdom & $-70 \%$ & $-31 \%$ & -74 & $-69 \%$ & $-43 \%$ & -50 \\
\hline Bulgaria & $-70 \%$ & $-23 \%$ & -16 & $-70 \%$ & $-39 \%$ & -11 \\
\hline Romania & $-65 \%$ & $-23 \%$ & -22 & $-65 \%$ & $-37 \%$ & -15 \\
\hline Croatia & $-58 \%$ & $-23 \%$ & -3 & $-58 \%$ & $-34 \%$ & -2 \\
\hline EU28 & $-65 \%$ & $-24 \%$ & -664 & $-65 \%$ & $-37 \%$ & -452 \\
\hline China & $-33 \%$ & $-44 \%$ & 664 & $-55 \%$ & $-62 \%$ & 452 \\
\hline China+EU28 & $-40 \%$ & $-40 \%$ & - & $-57 \%$ & $-57 \%$ & - \\
\hline
\end{tabular}

Poland. France, which has already decarbonized its electricity generation, is less interested in the linkage.

Figure 6 shows the impacts of the integrated markets on the competitiveness of energy intensive industries in both regions, measured as the percentage change of the production in China's high commitment scenario for the year 2040. The results clearly demonstrate that 


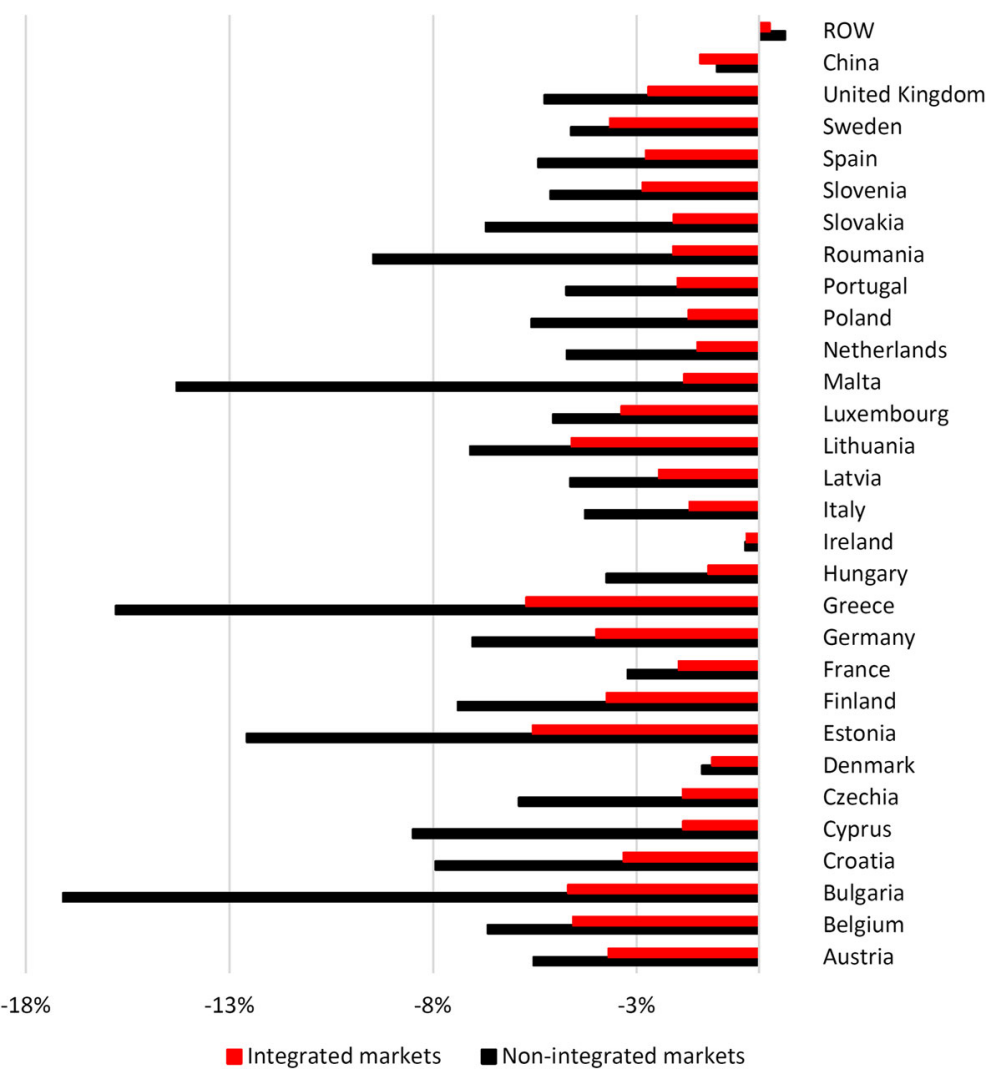

Fig. 6 Percentage change in production of energy intensive industries-year 2040 and high commitment scenario

an integrated EU and Chinese ETS market significantly reduces the loss of competitiveness of European energy intensive industries.

Finally, Fig. 7 shows the incremental percentage change of international leakage, i.e. the $\mathrm{CO}_{2}$ emissions increase in the ROW divided by the decrease in European and Chinese $\mathrm{CO}_{2}$ emissions. ${ }^{20}$ The international leakage is driven by two factors, namely the fall of international fossil energy prices followed by the decrease of energy consumption in EU and China, ${ }^{21}$ and the loss of competitiveness of European and Chinese industries that increases the demand of good produced by the ROW with correlative $\mathrm{CO}_{2}$ emissions. The resulting leakage is rather small, less than $12 \%$. Albeit integrating ETS markets limits the leakage effect by around one quarter, as the competitiveness loss of European energy intensive industries is reduced when the ETS markets are joined.

\footnotetext{
${ }^{20}$ The leakage effect is decomposed by using the following formula, where the EU's contribution is equal to:

$$
\frac{\triangle C O 2^{E U 28}}{\triangle C O 2^{E U 28}+\triangle C O 2^{C H I}} \cdot \frac{\triangle C O 2^{R O W}}{\triangle C O 2^{E U 28}+\triangle C O 2^{C H I}}
$$

${ }^{21}$ It follows that ROW without any emission constraint increases fossil energy consumption and $\mathrm{CO}_{2}$ emissions.
} 


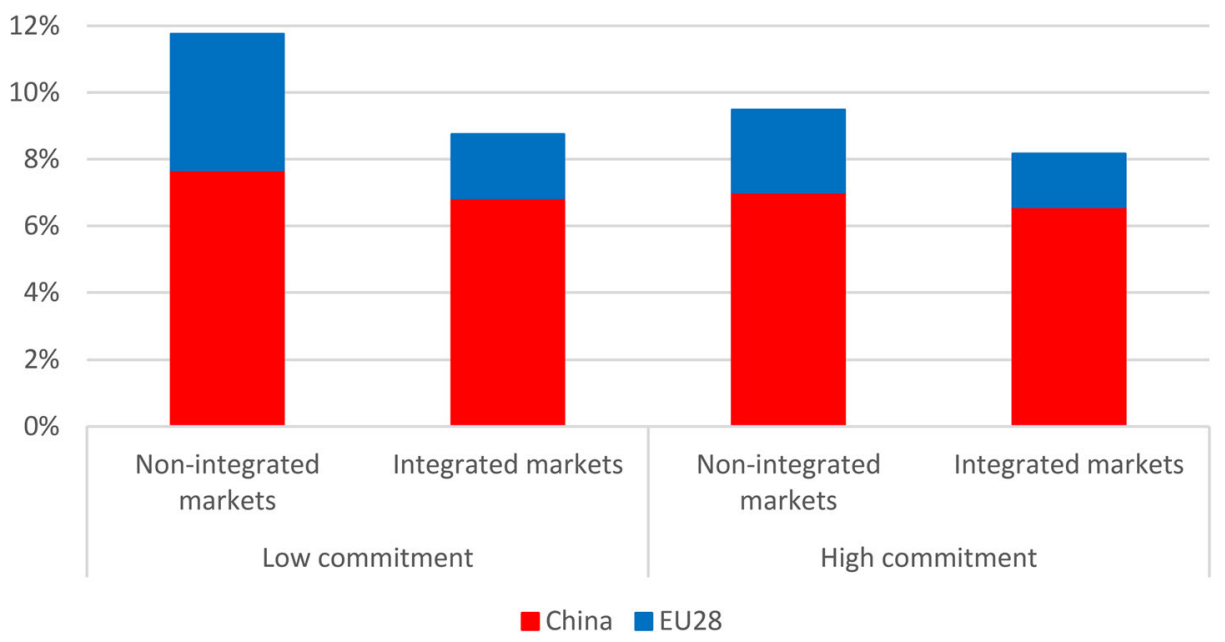

Fig. $7 \mathrm{CO}_{2}$ leakage in \%-year 2040

\subsection{Limit on trading}

In an integrated market, the share of $\mathrm{CO}_{2}$ allowances bought by European countries from China with respect to the initial commitment is quite large. Full participation in the integrated market with unlimited trading, however, might be politically unacceptable. It should be noted that the EU ETS legislation already allows the use of international credits, namely clean development mechanisms and joint implementation instruments with some limits. In 2013 to 2020, installations that already fell into the scope of the EU ETS in the period of 2008 to 2012 may use these credits for the period 2008 to 2020, up to a limit of $11 \%$ of their allocation for 2008 to 2012 (European Commission 2015a).

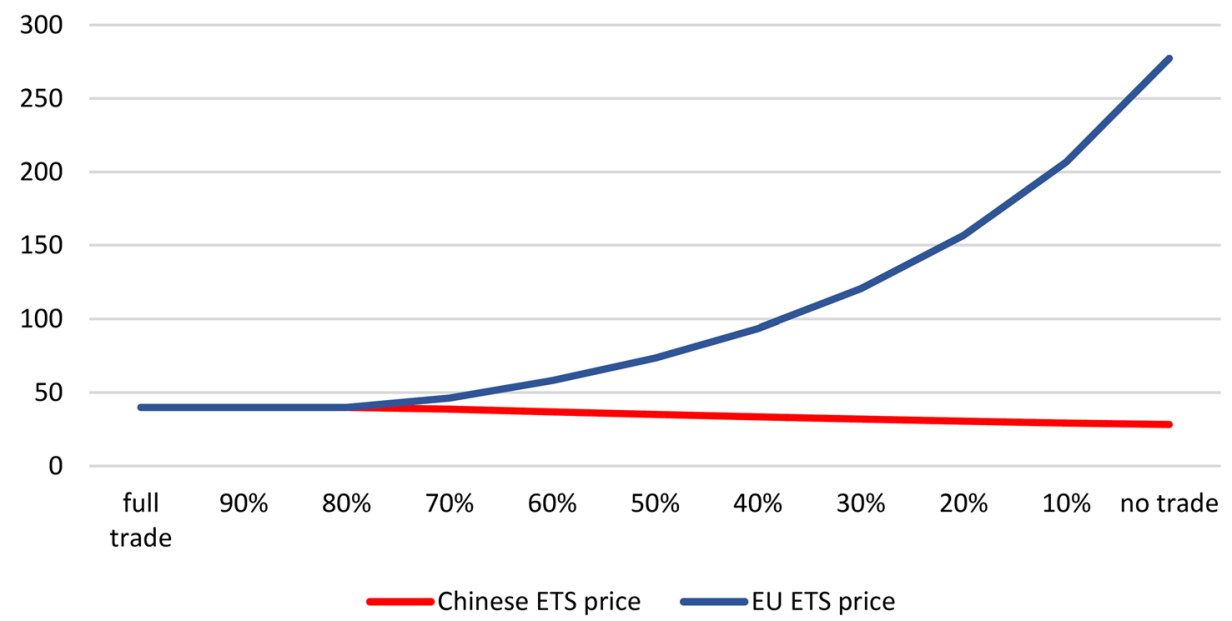

Fig. 8 ETS prices in $€$ with respect to trading limit-year 2040 and high commitment scenario 
Table 8 Welfare decomposition with respect to trade limits-year 2040 and high commitment scenario (in $\%$ of household consumption)

\begin{tabular}{|c|c|c|c|c|c|c|c|c|}
\hline & \multicolumn{4}{|l|}{ EU } & \multicolumn{4}{|l|}{ China } \\
\hline & Welfare & GTT & $\begin{array}{l}\text { Trade of } \\
\text { Quota }\end{array}$ & DWL & Welfare & GTT & $\begin{array}{l}\text { Trade of } \\
\text { Quota }\end{array}$ & DWL \\
\hline Full trade & $-1.74 \%$ & $2.37 \%$ & $-0.17 \%$ & $-3.94 \%$ & $-1.93 \%$ & $-0.67 \%$ & $0.38 \%$ & $-1.64 \%$ \\
\hline $90 \%$ & $-1.74 \%$ & $2.37 \%$ & $-0.17 \%$ & $-3.94 \%$ & $-1.93 \%$ & $-0.67 \%$ & $0.38 \%$ & $-1.64 \%$ \\
\hline $80 \%$ & $-1.74 \%$ & $2.37 \%$ & $-0.17 \%$ & $-3.94 \%$ & $-1.93 \%$ & $-0.67 \%$ & $0.38 \%$ & $-1.64 \%$ \\
\hline $70 \%$ & $-1.72 \%$ & $2.39 \%$ & $-0.15 \%$ & $-3.96 \%$ & $-1.96 \%$ & $-0.69 \%$ & $0.34 \%$ & $-1.61 \%$ \\
\hline $60 \%$ & $-1.71 \%$ & $2.41 \%$ & $-0.12 \%$ & $-4.00 \%$ & $-2.00 \%$ & $-0.71 \%$ & $0.28 \%$ & $-1.57 \%$ \\
\hline $50 \%$ & $-1.70 \%$ & $2.44 \%$ & $-0.10 \%$ & $-4.05 \%$ & $-2.04 \%$ & $-0.74 \%$ & $0.22 \%$ & $-1.52 \%$ \\
\hline $40 \%$ & $-1.72 \%$ & $2.47 \%$ & $-0.07 \%$ & $-4.11 \%$ & $-2.07 \%$ & $-0.75 \%$ & $0.17 \%$ & $-1.48 \%$ \\
\hline $30 \%$ & $-1.76 \%$ & $2.50 \%$ & $-0.05 \%$ & $-4.21 \%$ & $-2.09 \%$ & $-0.77 \%$ & $0.12 \%$ & $-1.44 \%$ \\
\hline $20 \%$ & $-1.83 \%$ & $2.53 \%$ & $-0.03 \%$ & $-4.33 \%$ & $-2.11 \%$ & $-0.79 \%$ & $0.08 \%$ & $-1.40 \%$ \\
\hline $10 \%$ & $-1.94 \%$ & $2.57 \%$ & $-0.02 \%$ & $-4.49 \%$ & $-2.12 \%$ & $-0.80 \%$ & $0.04 \%$ & $-1.36 \%$ \\
\hline No trade & $-2.10 \%$ & $2.62 \%$ & $0.00 \%$ & $-4.72 \%$ & $-2.13 \%$ & $-0.81 \%$ & $0.00 \%$ & $-1.32 \%$ \\
\hline
\end{tabular}

Several literature have already addressed the trading limit for China (Gavard et al. 2013; 2016; Li et al. 2019). Here, the same constraint is applied, keeping the assumption of China's commitment to a high abatement and varying the scenarios with limited trading from 10 to 90\% of the EU ETS target. In 2040, above 80\% trading limit, the constraint is no longer binding as the optimal percentage share of emissions bought in percentage of the EU ETS target is equal to $76.5 \%$. Figure 8 illustrates two ETS prices for the EU and China. China's ETS price decreases slightly with a linear trend as the trading limit becomes more and more binding (i.e when the trading limit decreases in percentage). In contrast, the EU ETS price increases when trading is more binding with a quadratic trend.

Table 9 Impact of trading limits on quotas trade, EU EEI production and domestic $\mathrm{CO}_{2}$ abatement-year 2040 and high commitment scenario

\begin{tabular}{llllll}
\hline & $\begin{array}{l}\text { Quota } \\
\text { selling } \\
\text { by China }\end{array}$ & $\begin{array}{l}\% \text { of quota } \\
\text { bought } \\
\text { by EU }\end{array}$ & $\begin{array}{l}\text { EU EEI } \\
\text { Production } \\
\text { change in } \%\end{array}$ & $\begin{array}{l}\mathrm{EU} \mathrm{CO}_{2} \\
\text { abatement } \\
\text { in \% }\end{array}$ & $\begin{array}{l}\text { China } \mathrm{CO}_{2} \\
\text { abatement } \\
\text { in \% }\end{array}$ \\
\hline Full trade & 452 & $76.5 \%$ & $-2.6 \%$ & $-38.7 \%$ & $-46.6 \%$ \\
$90 \%$ & 424 & $76.5 \%$ & $-2.6 \%$ & $-38.7 \%$ & $-46.6 \%$ \\
$80 \%$ & 401 & $76.5 \%$ & $-2.6 \%$ & $-38.7 \%$ & $-46.6 \%$ \\
$70 \%$ & 374 & $70.0 \%$ & $-2.7 \%$ & $-39.8 \%$ & $-46.3 \%$ \\
$60 \%$ & 342 & $60.0 \%$ & $-2.9 \%$ & $-41.5 \%$ & $-45.8 \%$ \\
$50 \%$ & 294 & $50.0 \%$ & $-3.1 \%$ & $-43.3 \%$ & $-45.3 \%$ \\
$40 \%$ & 236 & $40.0 \%$ & $-3.4 \%$ & $-45.0 \%$ & $-44.8 \%$ \\
$30 \%$ & 177 & $30.0 \%$ & $-3.7 \%$ & $-46.7 \%$ & $-44.3 \%$ \\
$20 \%$ & 118 & $20.0 \%$ & $-4.1 \%$ & $-48.4 \%$ & $-43.8 \%$ \\
$10 \%$ & 59 & $10.0 \%$ & $-4.6 \%$ & $-50.2 \%$ & $-43.3 \%$ \\
No trade & 0 & $0.0 \%$ & $-5.2 \%$ & $-51.9 \%$ & $-42.8 \%$ \\
\hline
\end{tabular}


The critical point is at the $40 \%$ trade limit. Above this threshold, the EU welfare is unchanged as the gain from trade is relatively small since the difference between ETS prices are reduced (see Table 8). From an European perspective, limiting the trade of quotas to $40 \%$ captures most of the welfare gain coming from $\mathrm{CO}_{2}$ trading. This would probably be politically acceptable in 2040 . Conversely, China's welfare is linearly correlated to the trade limit, thus full trade is more preferable. Limiting trade to $40 \%$ will not make the difference relative to a non-trade scenario (Table 9).

\section{Conclusion}

This paper assesses the economic impacts of joining European and Chinese ETS markets. A comparative analysis of individual and integrated ETS markets in the EU and China is performed, assuming that the Nationally Determined Contributions (NDCs) decided at COP21 in the Paris Agreement are implemented. The scenarios are simulated up to the year 2040, taking into consideration the latest climate commitments. The analysis leads to three significant points of conclusion.

First, the results show that the integration of the Chinese and European trading markets is beneficial for both the EU and China. Under the condition of no trading limit amongst participants, the integrated market creates a competitive carbon price that lowers welfare costs for both regions. With this price level, the EU could lower its emission reduction target by purchasing quotas, thus lowering the welfare cost by minimizing deadweight loss from emission abatement. The EU attains lower gain from terms of trade and experiences some trade loss by purchasing greater emission quotas, but these values are overcompensated by minimum amount of the allocative inefficiency by trading with China. In line with this, China's gains from the terms of trade and the emission quota exceeds a higher deadweight loss for more emission abatement under the integrated market scenario.

Second, the decomposition analysis reveals that most countries face lower welfare costs compared to the non-integrated market scenario. In complement to previous studies by Gavard et al. (2013), Gavard et al. (2016), Liu and Wei (2016), Zeng et al. (2018), and Li et al. (2019), we measure the economic impacts of linking ETS markets for each 28 European MS. Welfare costs from abatements decrease in some notable countries in which ETS constitutes a large part of their economies, such as Poland, Romania, the Czech Republic, and Croatia. A few others such as the Netherlands, Lithuania, Ireland and Estonia face an unavoidable higher welfare cost because of the dominance effect of loss from trade. Spatial sectoral analysis, however, finds that the linkage significantly minimizes the loss of competitiveness of the EU energy-intensive industries. International leakage due to market integration under the coordinated market is also rather small, which further confirms the potential of ETS as an effective instrument to facilitate multilateral coordination in global mitigation.

Third, limiting trade to $40 \%$ is likely to be a politically acceptable policy if both markets are integrated. Limiting the trade of quotas to this threshold captures most of the welfare gain coming from $\mathrm{CO}_{2}$ trading for the EU. The critical point is the $40 \%$ limit for the EU, as there is no significant change in EU welfare or from trade above this level. China's welfare, in contrast, is linearly correlated to the trade limit; thus, a higher commitment facilitating full trade is more preferable.

Finally, as China is moving into national wide implementation of carbon trading, introducing new targeted sectors in the potential integrated market analysis is important. Widening 
the scope of sectoral coverage in Chinese market will likely affect trading gains and welfare distribution of the EU MS. This clearly matters for our future work.

\section{Appendix A}

\section{A.1 Comparison between quotas in the seven pilot ETS regions and EU ETS}

Table 10 Comparison of china seven pilot ETS and EU ETS

\begin{tabular}{|c|c|c|c|}
\hline Country & ETS & Sectors and enterprise & Threshold \\
\hline China & Beijing & $\begin{array}{l}\text { Electricity, heat, cement, } \\
\text { petrochemical and other industrial } \\
\text { enterprises, service industries } \\
\text { and public transport }\end{array}$ & $\begin{array}{l}\text { Regulated unit with } 5 \text { thousand } \\
\text { (inclusive) tons of } \mathrm{CO}_{2} \text { emissions } \\
(2009-2012)\end{array}$ \\
\hline China & Shanghai & $\begin{array}{l}\text { Electricity, steel, } \\
\text { petrochemical, chemical, } \\
\text { airports, ports, shopping malls, } \\
\text { hotels, etc. }\end{array}$ & $\begin{array}{l}\text { Industrial sectors with more than } 20 \\
\text { thousand tons of } \mathrm{CO}_{2} \text { emissions } \\
\text { and non-industrial sectors with more } \\
\text { than } 10 \text { thousand tons of } \mathrm{CO}_{2} \\
\text { emissions (2010-2011) }\end{array}$ \\
\hline
\end{tabular}

China Guangdong Electricity, cement, steel,

Regulated unit with 20 thousand

petrochemical, aviation

(inclusive) tons of $\mathrm{CO}_{2}$ emissions

(2011-2012)

China Chongqing Electricity, electrolytic

Regulated unit with 20 thousand

$40 \%$ aluminum, ferroalloy, calcium (inclusive) tons of $\mathrm{CO}_{2}$ emissions carbide, caustic soda, cement, steel (2008-2012)

China Tianjin

Electricity, heat, steel,

Regulated unit with 20 thousand chemical, petrochemical, (inclusive) tons of $\mathrm{CO}_{2}$ emissions oil and gas exploration (2009-2012)

China Shenzhen Electricity, water, manufacturing, Industrial sectors with more than and large public buildings 3 thousand tons of $\mathrm{CO}_{2}$ emissions, and the public buildings with more than 10 thousand square meters

China Hubei Electricity, steel, chemicals, Annual energy consumption cement, automobile of more than 60 thousand manufacturing, non-ferrous tons tce (2010-2011) metals, glass, paper, etc 
Table 10 (continued)

\begin{tabular}{|c|c|c|c|c|}
\hline Country & ETS & Sectors and enterprise & Threshold & $\begin{array}{l}\text { Quota } \\
\text { covered }\end{array}$ \\
\hline $\mathrm{EU}$ & EU ETS & Electricity, industry and aviation & $\begin{array}{l}\text { Power stations and other combustion } \\
\text { installations with }>20 \mathrm{MW} \\
\text { thermal rated input (except hazardous } \\
\text { or municipal waste installations) } \\
\text { Aviation was introduced in } 2012 \\
\left(>10,000 \mathrm{tCO}_{2} / \text { year for }\right. \\
\text { commercial aviation; > }>1,000 \\
\mathrm{tCO}_{2} / \text { year for non-commercial } \\
\text { aviation since } 2013 \text { ) }\end{array}$ & $45 \%$ \\
\hline
\end{tabular}

Tang et al. (2020) and ICAP (2020)

\section{A.2 ESR target by Member State}

Table 11 Effort sharing decision (source: European Commission (2016b))

\begin{tabular}{|c|c|c|c|c|}
\hline & $\begin{array}{l}\text { GDP per capita } \\
\text { in } € \\
2013\end{array}$ & ESD target 2020 & $\begin{array}{l}\text { ESR target } 2030 \\
\text { in } \% \text { of } 2005 \text { levels }\end{array}$ & Target $2040^{\dagger}$ \\
\hline Bulgaria (BGR) & 5800 & $20 \%$ & $0 \%$ & $-19 \%$ \\
\hline Romania (ROU) & 7200 & $19 \%$ & $-2 \%$ & $-21 \%$ \\
\hline Croatia (HRV) & 10,200 & $11 \%$ & $-7 \%$ & $-26 \%$ \\
\hline Hungary (HUN) & 10,200 & $10 \%$ & $-7 \%$ & $-26 \%$ \\
\hline Poland (POL) & 10,200 & $14 \%$ & $-7 \%$ & $-26 \%$ \\
\hline Latvia (LAT) & 11,300 & $17 \%$ & $-6 \%$ & $-27 \%$ \\
\hline Lithuania (LIT) & 11,800 & $15 \%$ & $-9 \%$ & $-28 \%$ \\
\hline Slovakia (SVK) & 13,600 & $13 \%$ & $-12 \%$ & $-31 \%$ \\
\hline Estonia (EST) & 14,400 & $11 \%$ & $-13 \%$ & $-32 \%$ \\
\hline Czech Republic (CZE) & 14,900 & $9 \%$ & $-14 \%$ & $-33 \%$ \\
\hline Portugal (POR) & 16,300 & $1 \%$ & $-17 \%$ & $-35 \%$ \\
\hline Greece (GRE) & 16,500 & $-4 \%$ & $-16 \%$ & $-36 \%$ \\
\hline Slovenia (SVN) & 17,400 & $4 \%$ & $-15 \%$ & $-37 \%$ \\
\hline Malta (MLT) & 18,100 & $5 \%$ & $-19 \%$ & $-38 \%$ \\
\hline Cyprus (CYP) & 21,000 & $-5 \%$ & $-24 \%$ & $-43 \%$ \\
\hline Spain (SPN) & 22,100 & $-10 \%$ & $-26 \%$ & $-44 \%$ \\
\hline Italy (ITA) & 26,500 & $-13 \%$ & $-33 \%$ & $-50 \%$ \\
\hline United Kingdom (GBR) & 31,900 & $-16 \%$ & $-36 \%$ & $-55 \%$ \\
\hline France (FRA) & 32,100 & $-14 \%$ & $-36 \%$ & $-55 \%$ \\
\hline Germany (DEU) & 35,000 & $-14 \%$ & $-37 \%$ & $-57 \%$ \\
\hline Belgium (BEL) & 35,400 & $-15 \%$ & $-38 \%$ & $-57 \%$ \\
\hline Finland (FIN) & 37,400 & $-16 \%$ & $-39 \%$ & $-58 \%$ \\
\hline
\end{tabular}


Table 11 (continued)

\begin{tabular}{lllll}
\hline & $\begin{array}{l}\text { GDP per capita } \\
\text { in € } \\
2013\end{array}$ & ESD target 2020 & $\begin{array}{c}\text { ESR target 2030 } \\
\text { in of 2005 levels }\end{array}$ & Target 2040 \\
\hline Austria (AUT) & 38,100 & $-16 \%$ & $-39 \%$ & $-59 \%$ \\
Netherlands (NLD) & 38,700 & $-16 \%$ & $-39 \%$ & $-59 \%$ \\
Ireland (IRL) & 39,000 & $-20 \%$ & $-39 \%$ & $-59 \%$ \\
Sweden (SWE) & 45,400 & $-17 \%$ & $-40 \%$ & $-59 \%$ \\
Denmark (DNK) & 45,500 & $-20 \%$ & $-40 \%$ & $-59 \%$ \\
Luxembourg (LUX) & 85,600 & $-20 \%$ & $-40 \%$ & $-59 \%$ \\
\hline
\end{tabular}

These commitments refer to targets in the non-ETS part of the economy

'Own computation

\section{A.3 Nested CES production function}

Domestic production technologies are described through nested CES functions which differ according to the sector. Figure 9 shows the nested CES production structure of the

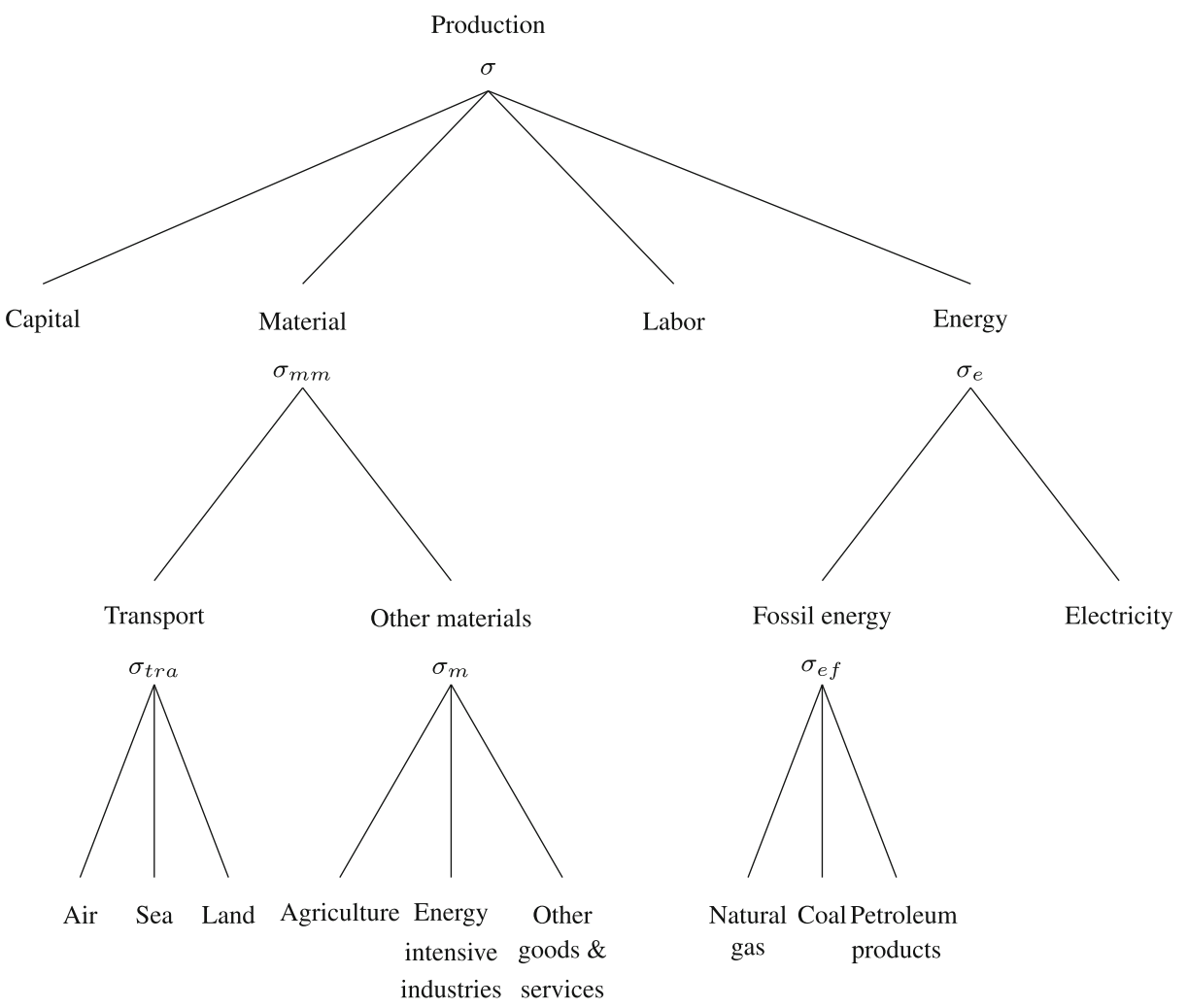

Fig. 9 Nested CES production structure of industrial sector 


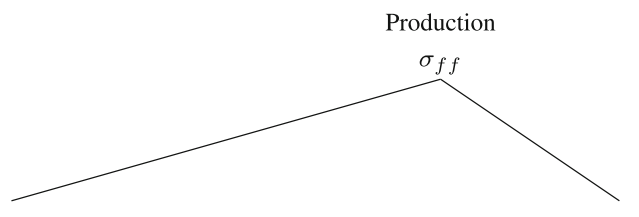

Fossil energy resource Other inputs

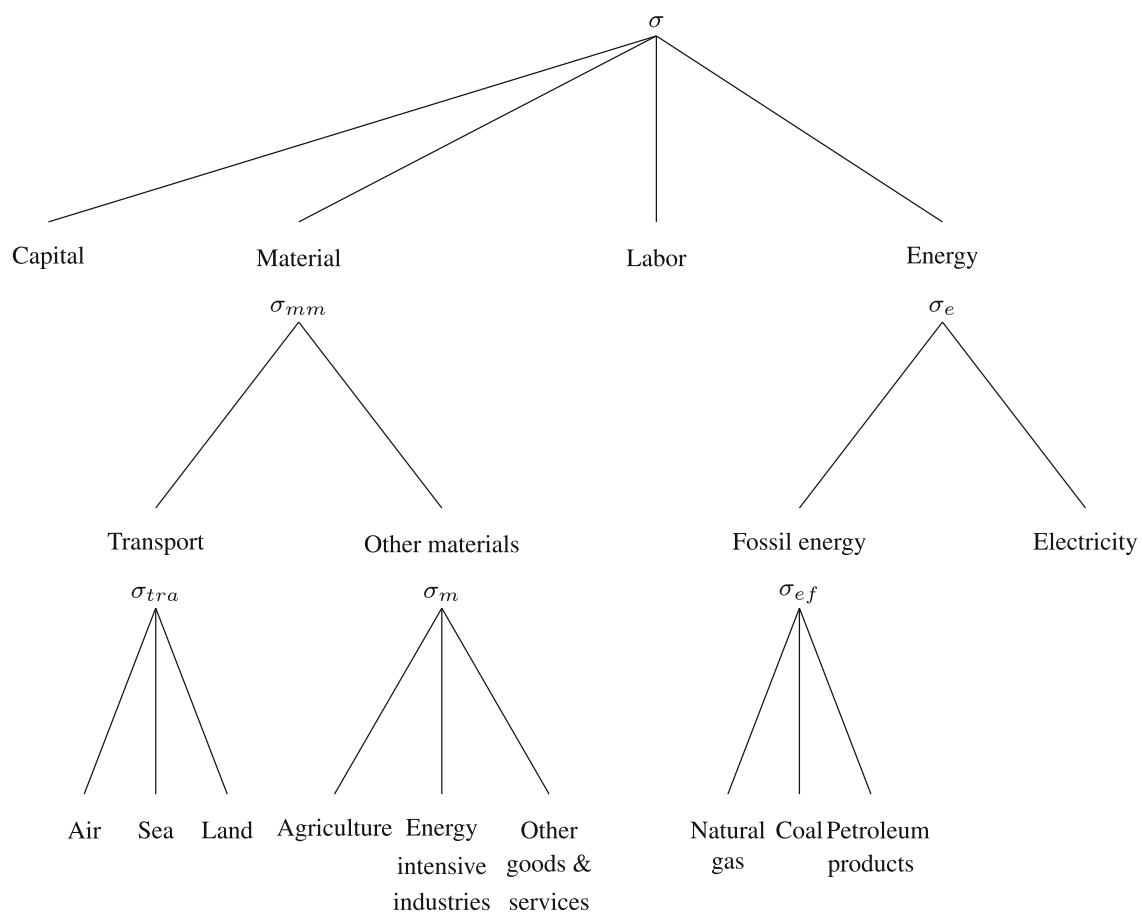

Fig. 10 Nested CES production structure of fossil energy producing sector (coal, natural gas and crude oil)

non-fossil energy sector. Production is carried out using four aggregates: capital, labor, material and energy. In a second step (nest), material and energy are decomposed in individual goods again using CES functions.

As shown in Fig. 10, coal, crude oil and natural gas sectors include at the top of the nested CES a fixed factor that represents the non-renewable resource associated with each fossil fuel energy. For these sectors it is supposed that the domestic production is realized with this fixed factor and the other standard inputs (i.e. capital, labor, material and energy) through a nested CES function.

Finally, refined petroleum products are produced from the basic input, that is crude oil. The model considers this specificity with a CES function between crude oil and other standards inputs at the top level of the nested CES structure.

\section{A.4 Nested CES household function}

Figure 11 shows the nested CES structure of the household consumption. At the first level of the consumption function, households choose between three aggregates: housing, transport 


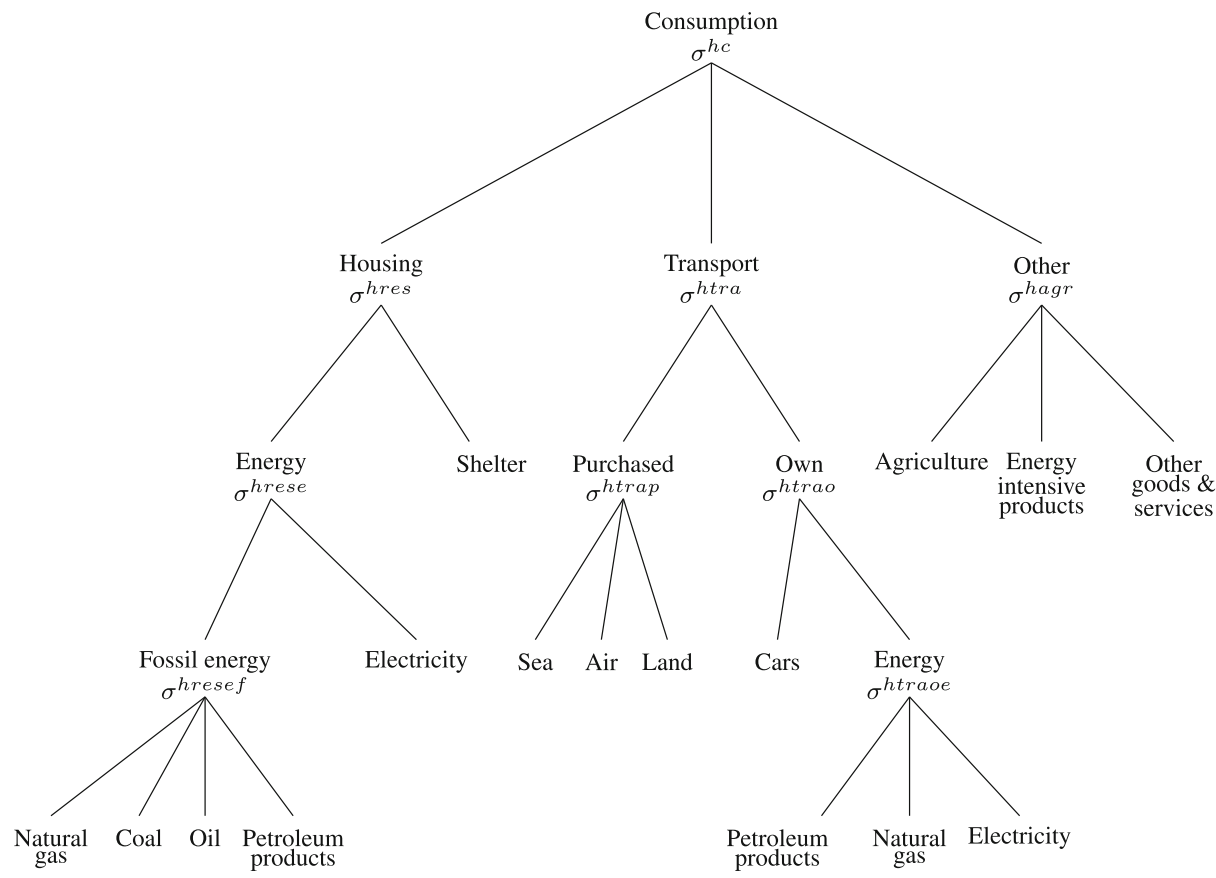

Fig. 11 Nested CES structure of household consumption

and other consumptions. Energy consumption is divided between transportation and housing purposes. In each nest, energy can be substituted by spending more on capital goods, cars in the first case and shelter in the second case, in other words, by purchasing more energyefficient but also more expensive cars and housing units.

Acknowledgements Thanks to Philippe Thalmann and participants of the 23rd Annual GTAP Conference for useful discussions on the topic. Also, tremendous thanks for three reviewers from Journal of Mitigation and Adaptation Strategies for Global Change, for their comments and suggestions to improve this paper.

Funding Open Access funding provided by EPFL Lausanne. This work was supported by the H2020 European Commission Project "PARIS REINFORCE" under grant agreement No. 820846.

Availability of data and materials An excel sheet that includes the numerical results will be provided once the paper is accepted and uploaded on a Zenodo space.

\section{Declarations}

Disclaimer The sole responsibility for the content of this paper lies with the authors. The paper does not necessarily reflect the opinions of the European Commission.

Open Access This article is licensed under a Creative Commons Attribution 4.0 International License, which permits use, sharing, adaptation, distribution and reproduction in any medium or format, as long as you give appropriate credit to the original author(s) and the source, provide a link to the Creative Commons licence, and indicate if changes were made. The images or other third party material in this article are included in the article's Creative Commons licence, unless indicated otherwise in a credit line to the material. If material is not included in the article's Creative Commons licence and your intended use is not permitted by statutory regulation or exceeds the permitted use, you will need to obtain permission directly from the copyright holder. To view a copy of this licence, visit http://creativecommons.org/licenses/by/4.0/. 


\section{References}

Aguiar A, Narayanan B, McDougall R (2016) An overview of the GTAP 9 data base. J Global Econ Anal 1(1):181-208

Alexeeva V, Anger N (2016) The globalization of the carbon market: welfare and competitiveness effects of linking emissions trading schemes. Mitig Adapt Strat Glob Chang 21(6):905-930

Armington P (1969) A theory of demand for products distinguished by place of production. IMF Staff Pap 16(1):159-78

Babiker M, Reilly J, Viguier L (2004) Is international emissions trading always beneficial? Energ J 25(2): 33-56

Bel Germà, Joseph S (2015) Emission abatement: untangling the impacts of the EU ETS and the economic crisis. Energ Econ 49:531-539

Bernard A, Vielle M (2003) Measuring the welfare cost of climate change policies: A comparative assessment based on the computable general equilibrium model GEMINI-E3. Environ Model Assess 8:199-217

Bernard A, Vielle M (2008) GEMINI-E3, a general equilibrium model of international-national interactions between economy, energy and the environment. Comput Manag Sci 5(3):173-206

Böhringer C., Rutherford TF (2002) Carbon abatement and international spillovers. Environ Resour Econ 22(3):391-417

Brink C, Vollebergh HRJ, van der Werf E (2016) Carbon pricing in the EU: evaluation of different EU ETS reform options. Energ Pol 97:603-617

Cao J, Ho MS, Jorgenson DW, Nielsen CP (2019) China's emissions trading system and an ETS-carbon tax hybrid. Energ Econ 81:741-753

Duan M, Qi S, Wu L (2018) Designing China's national carbon emissions trading system in a transitional period. Clim Pol 18(sup1):1-6

European Commission (2013) International carbon market. European commission climate action. https://ec. europa.eu/clima/policies/ets/markets_en

European Commission (2015a) EU ETS handbook

European Commission (2015b) The 2015 Ageing report: economic and budgetary projections for the $28 \mathrm{EU}$ member states (2013-2060). Directorate-general for economic and financial affairs

European Commission (2016a) EU Reference Scenario 2016

European Commission (2016b) Commission Staff Working Document Impact Assessment accompanying the document proposal for a regulation of the European Parliament and of the Council on binding annual greenhouse gas emission reductions by member states from 2021 to 2030 for a resilient energy union and to meet commitments under the paris agreement and amending regulation no 525/2013 of the european parliament and the council on a mechanism for monitoring and reporting greenhouse gas emissions and other information relevant to climate change

Fragkos P, Fragkiadakis K, Paroussos L, Pierfederici R, Vishwanathan SS, Köberle A. C, Iyer G, He ChenMin, Oshiro K (2018) Coupling national and global models to explore policy impacts of NDCs. Energ pol 118:462-473

Gavard C, Winchester N, Paltsev S (2013) Limited sectoral trading between the EU ETS and China. Technical report, MIT joint program report series

Gavard C, Winchester N, Paltsev S (2016) Limited trading of emissions permits as a climate cooperation mechanism? US-China and EU-China examples. Energ Econ 58:95-104

Goers SR, Pflüglmayer B, Luger MJ (2012) Design issues for linking emissions trading schemes - a qualitative analysis for schemes from europe, asia and north america. J Environ Sci Eng B1:1322-1334

Heindl P, Voigt S (2012) Supply and demand structure for international offset permits under the Copenhagen pledges. Int Environ Agree Pol Law Econ 12(4):343-360

Hepburn C, Grubb M, Neuhoff K, Matthes F, Tse M (2006) Auctioning of EU ETS phase II allowances: how and why? Clim Pol 6(1):137-160

Hu J, Crijns-Graus W, Lam L, Gilbert A (2015) Ex-ante evaluation of EU ETS during 2013-2030: EUinternal abatement. Energ Pol 77:152-163

Huang H, Roland-Holst D, Springer CH, Wang C (2019) How will an emissions trading system affect household income and social equity? a CGE-Based case study of China. Energ Procedia 158:4017-4022

Hübler M., Voigt S, Löschel A. (2014) Designing an emissions trading scheme for china-An up-to-date climate policy assessment. Energ Pol 75:57-72

ICAP (2020) Emissions Trading Worldwide: Status Report 2020. International Carbon Action Partnership, Berlin

International Energy Agency (2019) World Energy Outlook 2019

Jaffe JL, Stavins RN (2008) Linkage of tradable permit systems in international climate policy architecture. HKS Working paper no RWP08-053 
Ji Chang-Jing, Hu Yu-Jie, Tang Bao-Jun (2018) Research on carbon market price mechanism and influencing factors: a literature review. Nat Hazards 92:761-782

Ji Chang-Jing, Hu Yu-Jie, Tang Bao-Jun, Qu S (2021) Price drivers in the carbon emissions trading scheme: evidence from Chinese emissions trading scheme pilots. J Clean Prod 278:123469

Harrison JW, Mark Horridge J, Pearson KR (2000) Decomposing simulation results with respect to exogenous shocks. Comput Econ 15(3):227-249

Li M, Weng Y, Duan M (2019) Emissions, energy and economic impacts of linking China's national ETS with the EU ETS. Appl Energ 235:1235-1244

Lin B, Jia Z (2019) What will china's carbon emission trading market affect with only electricity sector involvement? a CGE based study. Energ Econ 78:301-311

Liu Y, Wei T (2016) Linking the emissions trading schemes of Europe and China - combining climate and energy policy instruments. Mitig Adapt Strat Glob Chang 21(2):135-151

Löschel A., Lutz BJ, Managi S (2019) The impacts of the EU ETS on efficiency and economic performancean empirical analyses for german manufacturing firms. Resour Energ Econ 56:71-95

Meng S, Siriwardana M, McNeill J, Nelson T (2018) The impact of an ETS on the Australian energy sector: an integrated CGE and electricity modelling approach. Energ Econ 69:213-224

Muûls M., Colmer J, Martin R, Wagner UJ (2016) Evaluating the eu emissions trading system: take it or leave it? an assessment of the data after ten years Grantham Institute briefing paper, vol 21. Imperial College, London

Nava CR, Meleo L, Cassetta E, Morelli G (2018) The impact of the EU-ETS on the aviation sector: competitive effects of abatement efforts by airlines. Transport Res Part A Pol Pract 113:20-34

Newell RG, Pizer WA, Raimi D (2014) Carbon market lessons and global policy outlook. Science 343(6177):1316-1317

Schäfer S (2019) Decoupling the EU ETS from subsidized renewables and other demand side effects: lessons from the impact of the EU ETS on $\mathrm{CO}_{2}$ emissions in the German electricity sector. Energ Pol 133:110858

Tang Bao-Jun, Ji Chang-Jing, Hu Yu-Jie, Tan Jin-Xiao, Wang Xiang-Yu (2020) Optimal carbon allowance price in China's carbon emission trading system: perspective from the multi-sectoral marginal abatement cost. J Clean Prod 253:119945

Tang B, Li R, Yu B, An R, Wei YM (2018) How to peak carbon emissions in China's power sector: a regional perspective. Energy Policy 120:365-381

Tol RSJ (2012) A cost-benefit analysis of the EU 20/20/2020 package. Energ Pol 49(C):288-295

Venmans F (2012) A literature-based multi-criteria evaluation of the EU ETS. Renew Sustain Energy Rev 16(8):5493-5510

Vielle M (2020) Navigating various flexibility mechanisms under European burden-sharing. Rev Environ Econ Policy 22(2):267-313

Wang Xu, Zhu L, Fan Y (2018) Transaction costs, market structure and efficient coverage of emissions trading scheme: a microlevel study from the pilots in china. Appl Energy 220:657-671

Wu R, Dai H, Geng Y, Xie Y, Masui T, Xu T (2016) Achieving china's INDC through carbon cap-and-trade: insights from Shanghai. Appl Energ 184:1114-1122

Xi J (2020) Statement by H.E Xi Jinping President of the People's Republic of China At the General Debate of the 75th Session of The United Nations General Assembly Ministry of Foreign Affairs of the People's Republic of China

Yang L, Li F, Zhang X (2016) Chinese companies' awareness and perceptions of the emissions trading scheme (ETS): evidence from a national survey in china. Energ Pol 98:254-265

Ying S, Jinhengi F (2017) Linking China's ETS with the EU ETS: possibilities and institutional challenges. Environ Pol Law 47(3-4):127-133

Zeng Y (2017) Indirect double regulation and the carbon ETSs linking: the case of coal-fired generation in the EU and china. Energ Pol 111:268-280

Zeng Y, Weishaar SE, Couwenberg O (2016) Absolute vs. intensity-based caps for carbon emissions target setting: a risk linking the EU ETS to the Chinese national ETS. Eur J Risk Reg 7:764

Zeng Y, Weishaar SE, Vedder HHB (2018) Electricity regulation in the Chinese national emissions trading scheme (ETS): lessons for carbon leakage and linkage with the EU ETS. Clim Pol 18(10):1246-1259

Zhu L, Wang X, Zhang D (2020) Identifying strategic traders in China's pilot carbon emissions trading scheme. Energ J 41(2)

Publisher's note Springer Nature remains neutral with regard to jurisdictional claims in published maps and institutional affiliations. 